\title{
Glass for Low-Cost Photovoltaic Solar Arrays
}

F.L. Bouquet

February 1, 1980

Prepared for

U.S. Department of Energy

Through an agreement with

National Aeronautics and Space Administration

by

Jet Propulsion Laboratory

California Institute of Technology

Pasadena, Californı

(JPL Publication 80-12) 


\section{DISCLAIMER}

This report was prepared as an account of work sponsored by an agency of the United States Government. Neither the United States Government nor any agency Thereof, nor any of their employees, makes any warranty, express or implied, or assumes any legal liability or responsibility for the accuracy, completeness, or usefulness of any information, apparatus, product, or process disclosed, or represents that its use would not infringe privately owned rights. Reference herein to any specific commercial product, process, or service by trade name, trademark, manufacturer, or otherwise does not necessarily constitute or imply its endorsement, recommendation, or favoring by the United States Government or any agency thereof. The views and opinions of authors expressed herein do not necessarily state or reflect those of the United States Government or any agency thereof. 


\section{DISCLAIMER}

Portions of this document may be illegible in electronic image products. Images are produced from the best available original document. 


\title{
Glass for Low-Cost Photovoltaic Solar Arrays
}

\author{
F.L. Bouquet
}

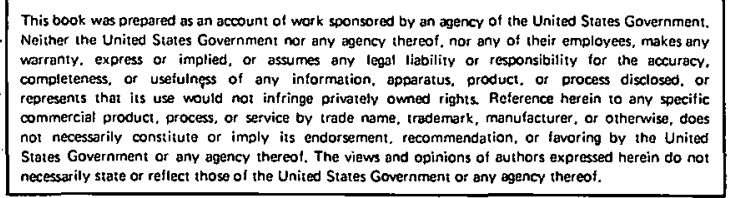

February 1, 1980

Prepared for

U.S. Department of Energy

Through an agreement with

National Aeronautics and Space Administration

by

Jet Propulsion Laboratory

California Institute of Technology

Pasadena, California

(JPL Publication 80-12) 
Prepared by the Jet Propulsion Laboratory, California Institute of Technology, for the Department of Energy through an agreement with the National Aeronautics and.Space Administration.

The JPL Low-Cost Solar Array Project is sponsored hy the Department of Energy (DOF) and forms part of the Solar Photovoltaic Conversion Prugran lu initiate a majnr effort toward the development of low-cost solar arrays.

This report was prepared as an account of work sponsored by the United States Govcrnment. Neither the United States nor the United States Department of Energy, nor any of their employees, nor any of their contractors, subcontractors, or their employees, makes any warranty, express or implied, or assumes any legal liability or responsibility for the accuracy, completeness or usefulness of any information, apparatus, product or process disclosed, or represents that its use would nut infringe privately owned rights. 


\section{ABSTRACT}

In photovoltaic systems, the encapsulant material that protects the solar cells should be highly transparent and very durable. Glass satisfies these two criteria and is considered a primary candidate for low-cost, photovoltaic encapsulation systems. In this report, various aspects of glass encapsulation are treated that are important for the designer of photovoltaic systems. Candidate glasses and available information defining the state of the art of glass encapsulation materials and processes for automated, high volume production of terrestrial photovoltaic devices and related applications are presented. The criteria for consideration of the glass encapsulation systems were based on the LSA (Low-cost Solar Array) Project goals for arrays: (a) a low degradation rate, (b) high reliability, (c) an efficiency greater than 10 percent, (d) a total array price less than $\$ 500 / \mathrm{kW}$, and (e) a production capacity of $5 \mathrm{x} 10^{5} \mathrm{~kW} / \mathrm{yr}$.

The glass design areas treated herein include the types of glass, sources and costs, physical properties and glass modifications, such as antireflection coatings. 
THIS PAGE

WAS INTENTIONALLY

LEFT BLANK 
The research described in this report was carried out at the Jet Propulsion Laboratory, Applied Mechanics Technology Section, California Institute of Technology, and was sponsored by the U.S. Department of Energy through an agreement with the National Aeronautics and Space Administration.

\section{ACKNOWLEDGMENT}

Contributions to this study were made by the personnel of BattelleColumbus Laboratories. Their report "Review of World txperience and Properties of Materials for Encapsulation of Terrestrial Photovoltaic Arrays", ERDA/JPL$954328-76 / 4$ is used as a major source of data for this report.

In addition, special contributions to the study are acknowledged from the Applied Mechanics Technology Section, Applied Mechanics Division, Jet Propulsion Laboratory, California Institute of Technology as follows:

R. F. Holtzc

H. G. Maxwe11 
THIS PAGE

WAS INTENTIONALLY.

LEFT BLANK 
CONTENTS

I.

GENERAL $1-1$

A. FORMS OF GLASS --

B. DIFFERENT TYPES OF GLASS FOR PHOTOVOLTAIC APPLICATIONS ------- 1-2

C. PHYSICAL PROPERTIES --

D. COMMERCIAL SOURCES OF GLASS -

E. COSTS OF GLASS -

II. CLASS PROCESSING -.. $2-1$

A. GLASS IMPROVEMENTS -

B. BONDING TO GLASS SURFACES -

III. GLASS AGING -----

IV. GLASS PERFORMANCE --

A. GENERAL -- $4-1$

B. SPECTRAL CHARACTERISTICS --

C. HAIL RESISTANCE -

D. WIND RESISTANCE ---

E. ABRASION EFFECTS --

V. CONCLUSIONS --

REFERENCES - - -

GLOSSARY - - - 


\section{Figures}

1. Solar Transmission for Soda-Lime Glass vs. Iron Level --_---------- 1-6

2. Linear Expansion of Glasses with Temperature ----------------------- 1-11

3. Expansion-Temperature Curves for Typical Corning Glasses ------------ 1-12

4. Thermal Conductivity of Corning Glasses --------------------- 1-12

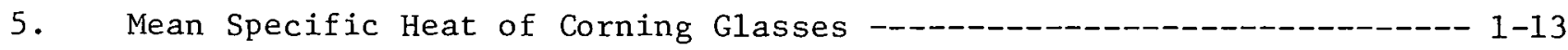

6. Young's Modulus of Various Glasses -- -

7. Viscosity - 'lemperature lurves of Various corning Glasses -------=-== $1-14$

8. Volume Resistivity for Variou's Corning Glasses ----------------- 1-14

9. Surface Resistivity of Corning Glasses vs. Relative Humidity -------- 1-15

10. Dielectric Strength vs. Temperature of Corning Glasses ------------ 1-15

11. Power Factor vs. Temperature for Corning Glass ---------------- 1-16

12. Variation of Dielectric Constant with Glass Temperature

for Various Corning Classes -

13. Glass Cost Data -

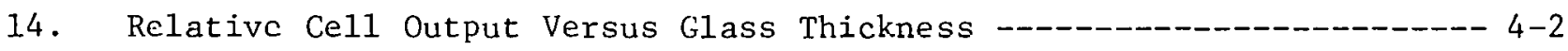

15. Refractive Index Versus Wavelength for Several Transparent

Matoriale - ===---_--_-_-_-_- $4-2$

16. The External Transmittance of Several Samples of

Corning and Amersil Glasses --

17. Spectral Transmittance Versus Wavelength for

1/4-Inch Clear Float Glass -.-_- 4-4

18. Transmission Versus Wavelength for Schott Low-Iron

Silicate Solawite ${ }^{K}$

19. Relative Transmittance of Materials After Exposure at

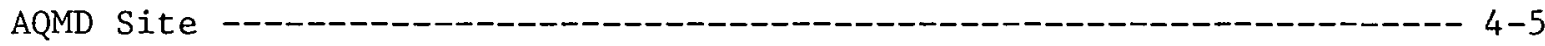

20. Cumulative Effects of Dirt -

21. Type of Photovoltaic Panel Material Versus Simulated Hailstone Diameter ---_-- 
22. Recommended Design Values for Breakage Strength Versus Probability of Failure for 1 Square Meter, Simply-Supported, Annealed Glass Plates Subjected to a Uniform Normal Pressure Load of 1-Minute Duration --_-_-_-_ 4-8

23. Velocity Parameter Versus Transmissivity Loss for Soda Lime Glass and Plastic --_-_-_-_-_-_ 4-9

Tables

1. Property Data for Selected Candidate Encapsulation Materials ------_-_-_-_-_-

2. Properties Which Characterize Glass --

3. Ranges of Physical Properties of Glass Types Compared to Silicon -- - -

4. Range of Physical Properties of Glass -

5. Comparative Analysis and Properties of Specific Representative

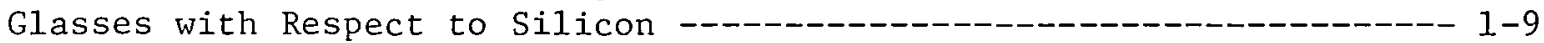

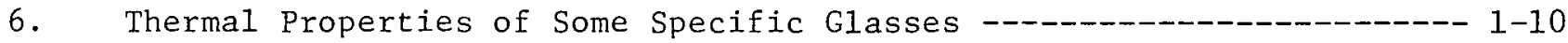

7. ASTM Tests Pertaining to Glass -

8. List of Domestic Glass Manufacturers and Sales Contracts ------------ 1-18

9. List of Foreign Manufacturers of Flat Glass -

10. Availability of Float Glass from One Manufacturer --------------- 1-20

11. Trade Names and Suppliers of Glass Materials -----_--------------- 1-20

12. Typical Large Volume Glass Costs --_-_--- 1-22

13. Typical Prices for Medium Thickness Glass -

1.4. Typica1, Prices for T.ow-Iron Soda-T.ime Glass ------------------- 1.-24

15. Lowest Possible Prices for Annealed Flat Glass --------------------- 1-26

16. Simplified Batch Formulation and Raw-Material Costs for

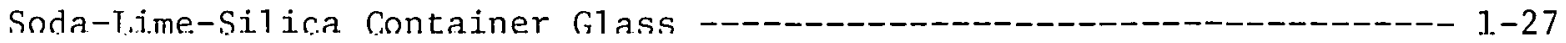

17. Simplified Batch Formulation and Raw-Material Costs for Low-Expansion Borosilicate Glass 
18. Total Energy Consumed in Manufacturing Various Types

of Materials --_-_-_-_-_-

19. Estimates of Prices of Photovoltaic Glass for Large

Quantities -

20. Summary of Recent Observations on Glass Weathering -

21. Solar Transmittance Properties of Manufactured Glass ---------------- 4-3 


\title{
SECTION I
}

\author{
GENERAL
}

\section{A. FORMS OF GLASS}

Glass is available in over 10,000 types and many different forms (References 1-16). Although flat glass is undoubtedly the most familiar type, glass is available with a wide variation of physical characteristics such as sagged (curved) or foamed. The detailed physical properties of the glass vary widely depending upon the manufacturing process and the chemical composition. The processability, environmental durability and prices of photovoltaic glass vary widely from different procurement sources.

It is the purpose of this report to briefly identify the above properties and characteristics of glass applicable for terrestrial photovoltaic encapsulation systems. See References 17-31. The first basic characteristic is the form of the glass and these are listed below.

\section{Flat Glass}

Flat glass can be classified as sheet, plate or float. Sheet glass is the most common form used in ordinary windows. Plate or float glass is used when exceptionally clear and accurate vision is needed, such as automobile windows. Although sheet glass is taken from the melting furnace with no additional polishing, plate glass is carefully ground and polished to smooth the surface. Float glass, however, is made by floating a ribbon of glass on a surface of hot, molten metal to produce smoother, more perfect parallel surfaces. Flat glass is available in many sizes and thicknesses. Typical available thicknesses vary from $0.7 \mathrm{~mm}$ ( 0.028 inch) to $2.54 \mathrm{~mm}$ (1.0 inch). Without special manufacturing capability, the maximum dimension is $\cong 3.05$ meters ( 120 inches).

\section{Cloth}

Glass comes also in the form of continuous fibers that can be incorporated into another material or be weaved into cloth.

\section{Laminated Glass}

Especially strong glass can be made using laminated layers of plastic and glass. Upon breakage, the plastic layer becomes elastic and stretches. This holds the broken pieces of glass together and is considerably safer than other types.

\section{Bullet-Resistant Glass}

In thicknesses of several inches, multilayered laminated glass will stop projectiles even at short range. 


\section{Tempered Safety Glass}

Unlike laminated glass, tempered safety glass is a single sheet that has been given special heat treatment. Although it appears to be similar to other types of glass in weight and thickness, it can be up to five times as strong against impact. It may be used as an alternate to laminated glass.

6. Foam Glass

Foam glass is made with many tiny bubbles throughout the material matrix and is extremely lightweight. It is used principally in special situations, such as insulation or on chemical equipment.

\section{7. lleat-resistant Glaoo}

This type of glass is high in silica and usually contains boric oxide. Its low coefficient of thermal expansion permits it to withstand severe temperdiure shock without breaking.

\section{Coated Glass}

Glass for special applications is available in many coated forms. Metallic or other surface coatings can be applied to produce superior transmissivity, reflectance or thermal control. Coatings are applied through sputtering vacuum deposition or ion implantation on the surface. Tin oxide coatings are used to increase surface conductivity in some electrical applications.

\section{Insulation}

When glass fipber batting is made from relaclvely lmpule maleidals fus insulation purposes, it is called rock or mineral wool.

10. Glass fibers

I.arge special glass fibers are used for light transmission while small glass fibers are used for strengthening materials. The fibers may be continuous (see cloth above) or discontinuous as used in fiberglass.

Many other categories of glass exist such as optical, photochromic, heat conducting and photosensitive glass. The reader is referred to the References, especially Reference 1, 5 and 32, for further details on glass forms. However, the emphasis in this report is on the types of glasses useful in photovultalc applications which are treated in the following section.

\section{B. DIFFERENT TYPES OF GLASS FOR PHOTOVOLTAIC APPLICATIONS}

Considerable experience with glass encapsulation for space and terrestrial applications has evolved. See Reference 28. So far, over 8 years experience have accrued on terrestrial modules under controlled conditions. The major features of the terrestrial experience to date with encapsulation systems in which glass constituted at least one component of the system can be summarized in terms of glass weatherability and encapsulation design (including optical 
coupling). Two general classes of glasses, soda-lime - silica and borosilicate, have exhibited acceptable weatherability over periods as long as about 16 years as covers in photovoltaic arrays. When hermetic seal function has been maintained, arrays have not experienced any serious degradation in electrical output attributable to lack of performance of the glass itself. Glass failures per se have stemmed from the material's fragility under shock loading. See Section IV in this report entitled Glass Performance.

Because of the necessity to use most glasses in a preformed shape, the selection of candidate glasses and processes for employing them depends heavily upon the array or module design. Moreover, the availability of many glasses in only limited shapes and forms also dictates that the selection be design dependent. Accordingly, the representative samples of candidate glasses given in the tabulation below are matched to selected design concepts. See Table 1.

The two main types of glasses useful for low-cost photovoltaic modules that have emerged from JPL research are soda-lime and borosilicate. The sodalime glass with low iron content is preferred because of its high transmissivity, availability and low cost. Examples are ASG's Sunadex ${ }^{R}$, ASG's Solarex ${ }^{R}$, and Fourco's Clearite ${ }^{R}$. Low expansion borosilicate glass is exemplified by Corning's

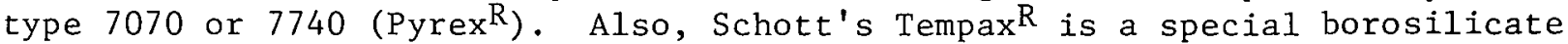
glass that is extremely resistant to thermal shocks.

Further details on the physical properties of glass for photovoltaic applications are given in the following section.

\section{PHYSICAL PROPERTIES}

The type of glass needed for photovoltaic applications has low distortion and low solar absorptance properties. Since iron is a known element that reduces optical transmittance, it is important that the glass should have low-iron content. The effect of iron on solar transmittance for various glass thicknesses is shown in Figure 1. Reduction of optical transmission in the module glass, of course, results in a corresponding reduction in electrical cell output. See section IV entitled Glass Performance.

The general properties of glass can be arbitrarily divided into 12 categories. See Table 2. Glasses have properties that can vary over wide ranges depending upon the chemical composition. For example, typical ranges are shown in Tables 3 and 4. Silicon properties are shown in Table 3 for comparison. The borosilicates come closest to matching the coefficient of expansion of the silicon solar cell.

Cilass is composed primarily of $\mathrm{SiO}_{2}$ but a few other oxides (such as $\mathrm{B}_{2} \mathrm{O}_{3}$ or $\mathrm{P}_{2} \mathrm{O}_{5}$ ) can form similar networks, and yet others (such as $\mathrm{AI}_{2} \mathrm{O}_{3}$ ) enter into the $\mathrm{SiO}_{2}$ network. See Table 5. Many other oxides (e.g., $\mathrm{Na}_{2} \mathrm{O}, \mathrm{CaO}, \mathrm{Pb} 0$ ) depolymerize the network by breaking up oxygen-to-oxygen bonds; their oxygen attaches itself to a free bond, while the metal atom, in the ionic state, is distributed randomly. Depolymerization lowers the bond strength, thus also the melting point and the viscosity at a given temperature, making the glass more suitable for manufacturing purposes. See Table 6 . Ninety percent of all glass produced is 
Table 1. Property Data For Seleczed Candidate Encapsulation Materials (Ref. 28.)

\begin{tabular}{|c|c|c|c|c|c|c|c|c|c|c|c|c|}
\hline \multirow[b]{2}{*}{ Property ${ }^{\text {(a) }}$} & \multicolumn{7}{|c|}{ Soda-Line-Siliza Glasses } & \multicolumn{5}{|c|}{ Boros:licate Giasses } \\
\hline & $\begin{array}{l}\infty \\
8 \\
01 \\
0 \\
E \\
E \\
\dot{0}\end{array}$ & 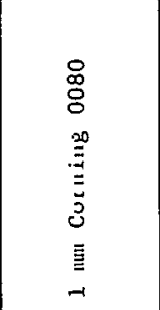 & 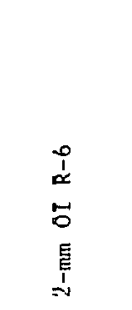 & 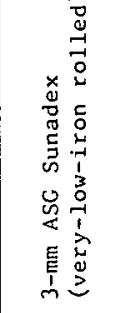 & 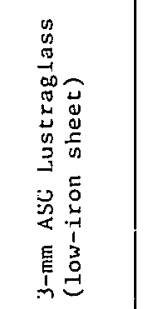 & 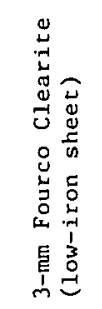 & 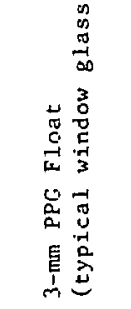 & 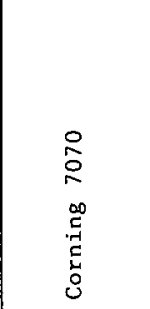 & 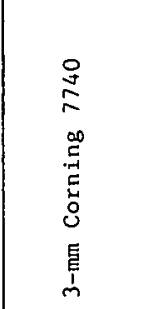 & 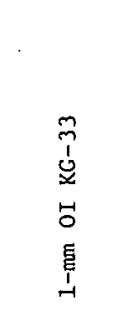 & 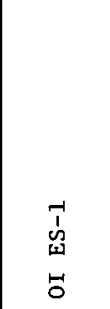 & 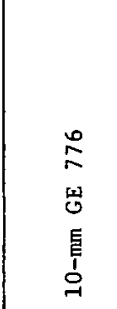 \\
\hline Transmittance & & & & & & & & & & & & \\
\hline Visible, at $500 \mathrm{~mm}$, Fercent & 91.5 & 92 & & 91 & 92 & 91.9 & 90 & - & 90 & 92 & - & 92 \\
\hline $\begin{array}{l}\text { IR, at } 1000 \mathrm{~nm}, \text { percent } \\
\text { Range > } 10 \text { percenr, }\end{array}$ & $0.29-6.7$ & $0.3-4.5$ & $0.92-32-4=$ & 90 & 86 & 86.5 & 64 & - & 88 & $0.28-3.5$ & - & 93 \\
\hline Refractive Index & 1.512 & 1.51 & 1.52 & 1.519 & 1.510 & 1.516 & 1.518 & 1.269 & 1.474 & 1.47 & 1.47 & 1.472 \\
\hline $\begin{array}{l}\text { Retractive index } \\
\text { Denstity, } 10^{-3} \mathrm{~kg} / \pi^{3}\end{array}$ & 2.48 & $\begin{array}{l}1.31 \\
2.47\end{array}$ & 2.53 & 2.5 & $\begin{array}{l}1.510 \\
2.5\end{array}$ & -1.0 & 2.5 & 2.13 & $\begin{array}{l}1.474 \\
2.23\end{array}$ & 2.23 & 2.12 & 2.22 \\
\hline Thermal Conductivity, w/mK @ $273 \mathrm{~K}$ & -2 & 1.05 & 1.02 & 0.91 & 0.91 & - & 0.94 & & 1.09 & 1.13 & 1.09 & \\
\hline Expansion Coef ficient, $10^{-7 / C}$ & 93 & 93.5 & 93 & 88 & 88 & 92.2 & 86 & 32 & 32.5 & 32 & 33 & 33 \\
\hline $\begin{array}{l}\text { Youngs Modulus, } 10^{10} \mathrm{~N} / \mathrm{m}^{2}\left(10^{6} \mathrm{psi}\right) \\
\text { Polssons Rat10 }\end{array}$ & $\begin{array}{l}6.9(10) \\
0.24\end{array}$ & $\left|\begin{array}{cc}7.0 & (10.2) \\
0.22\end{array}\right|$ & - & & - & $\begin{array}{l}- \\
-\end{array}$ & $\begin{array}{c}6.9(10) \\
0.22\end{array}$ & $\begin{array}{c}5.1(i .4) \\
0 .: 2\end{array}$ & $\begin{array}{c}6.3(9.1) \\
0.20\end{array}$ & - & - & - \\
\hline Straln Point, C & & 472 & 485 & $500^{\circ}$ & $500^{\circ}$ & - & - & 456 & 510 & 513 & 430 & 475 \\
\hline Annealing Point, $c$ & 515 & 5.14 & 525 & 550 & 550 & - & - & 476 & 560 & 565 & 476 & 525 \\
\hline Sof tening Point, $c$ & 700 & 696 & 700 & 780 & 780 & - & 721 & - & 821 & 825 & 745 & 775 \\
\hline Chemical Composition, Fercent (b) & 72.3 & $7=$ & & & & 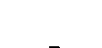 & 73.1 & $70,72(c)$ & 80.5 & _. & _- & 2780 \\
\hline $\begin{array}{l}\mathrm{SiO}_{2} \\
\mathrm{Na}_{2} \mathrm{O}\end{array}$ & $\begin{array}{l}2.3 \\
16.3\end{array}$ & $\begin{array}{l}1.0 .0 \\
16.0\end{array}$ & $\overline{-}$ & $=$ & $=$ & - & 3.1 & 0 & $\begin{aligned} 80.3 \\
3.8\end{aligned}$ & - & - & $\left.\right|^{2 / 8.0}$ \\
\hline $\mathrm{K}_{2} \mathrm{O}$ & 0.3 & 0.6 & - & - & - & - & 0.03 & $0.5 / 1.5$ & 0.4 & - & - & - \\
\hline $\mathrm{L}_{2} \mathrm{O}$ & - & - & - & - & - & - & & $1-2,-$ & - & - & - & - \\
\hline $\mathrm{CaO}$ & 5.0 & 0.3 & - & - & - & - & 8.87 & $0.1,-$ & - & - & - & - \\
\hline MgO & 3.5 & 5.6 & - & - & - & - & 3.89 & $0.2 p-$ & - & - & - & - \\
\hline $\mathrm{Al}_{2} \mathrm{O}_{3}$ & 1.9 & 0.6 & - & - & - & - & 0.13 & $1.1,-$ & 2.2 & - & - & - \\
\hline $\mathrm{Fe}_{2} \mathrm{O}_{3}$ & - & - & - & 0.02 & $0.05-0.05$ & 0.06 & 0.09 & $28 / 15$ & 129 & - & - & 2.0 \\
\hline $\begin{array}{l}\mathrm{B}_{2} \mathrm{O}_{3} \\
2 \mathrm{nO}\end{array}$ & $=$ & $\overline{-}$ & - & - & $\overline{-}$ & - & - & $\begin{array}{l}28 / 25 \\
-\end{array}$ & 12.9 & - & - & 213.0 \\
\hline $\mathrm{TiO}_{2}$ & - & - & - & - & - & - & - & $\overline{0} \overline{1.0}$ & - & - & - & - \\
\hline $\begin{array}{l}\mathrm{As}_{2} \mathrm{O}_{3} \\
\text { Weatherab1lity (d) }\end{array}$ & $\bar{c}$ & $\bar{c}$ & $1 ; c$ & B & B & B & в & B & $\overline{\mathrm{A}}$ & A & B & B \\
\hline
\end{tabular}

(a) Information compiled from vartous sources.

(b) Com glass, all of which provide similar properties.

(d) Est1mated rarking: $A=$ no veatherabiilty problem an:icipated. $B=$ may weather under some circunstances; $C=$ weathering could be a problem. 
Table 1. Property Data For Selected Candidate Encapsulation Materials (Continuation 1)

\begin{tabular}{|c|c|c|c|c|c|c|c|}
\hline \multirow[b]{2}{*}{ Property ${ }^{(a)}$} & \multicolumn{7}{|c|}{ Special or Development Glasses } \\
\hline & 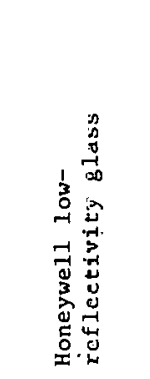 & 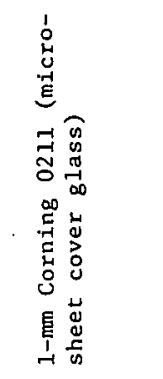 & 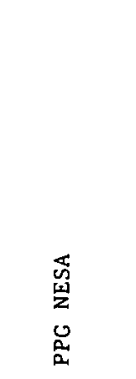 & 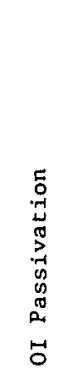 & 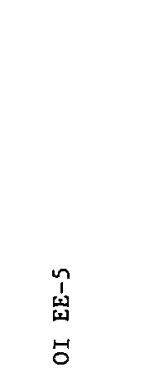 & 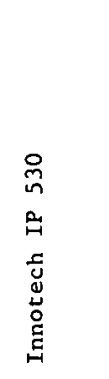 & 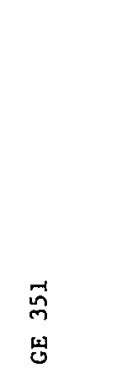 \\
\hline 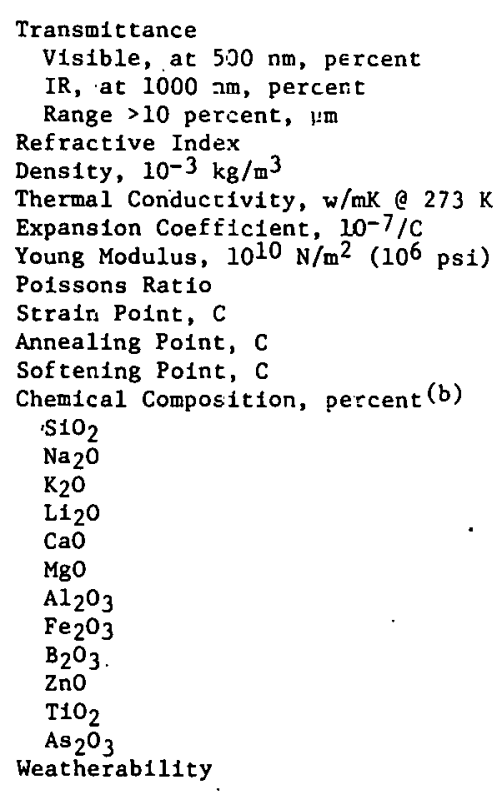 & 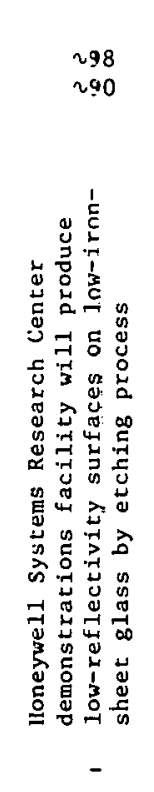 & $\begin{array}{c}92 \\
92 \\
0.32-4.5 \\
1.523 \\
2.57 \\
0.56 \\
73.8 \\
7.4(10.8) \\
0.22 \\
508 \\
550 \\
720 \\
65.5 \\
7.1 \\
7.1 \\
- \\
- \\
2.3 \\
10.0 \\
- \\
2.7 \\
-7 \\
B\end{array}$ & 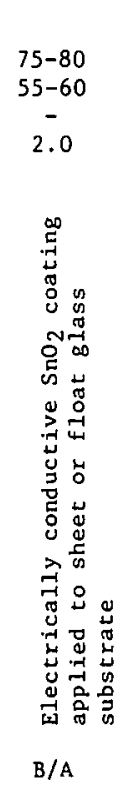 & 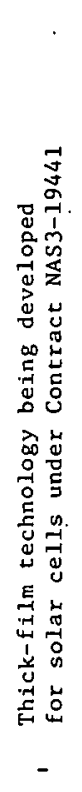 & 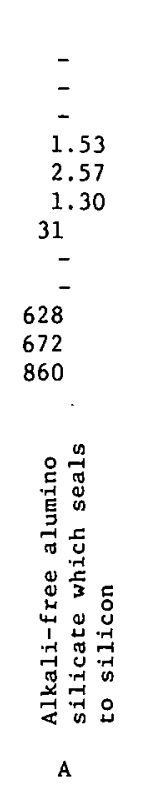 & 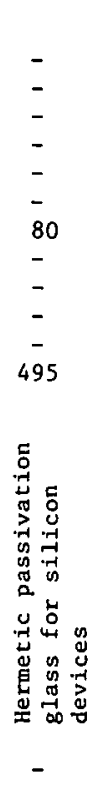 & 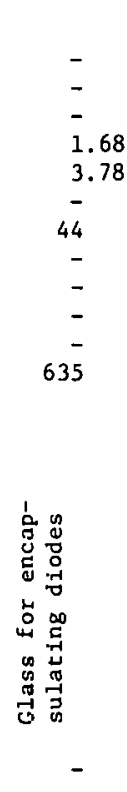 \\
\hline
\end{tabular}

(a) Information complied from various sources.

(b) Compositional Infcrmation provided to indicate approximate chemistry of glass because manufaciurers often have several batch formulations for same glass, all of which provide similar properties.

(c) Data from two different sources.

(d) Estimated rank1ng: $A=$ no weatherability problem anticipated; $B=$ may weather under some circumstances; $C=$ weathering could be a problem. 


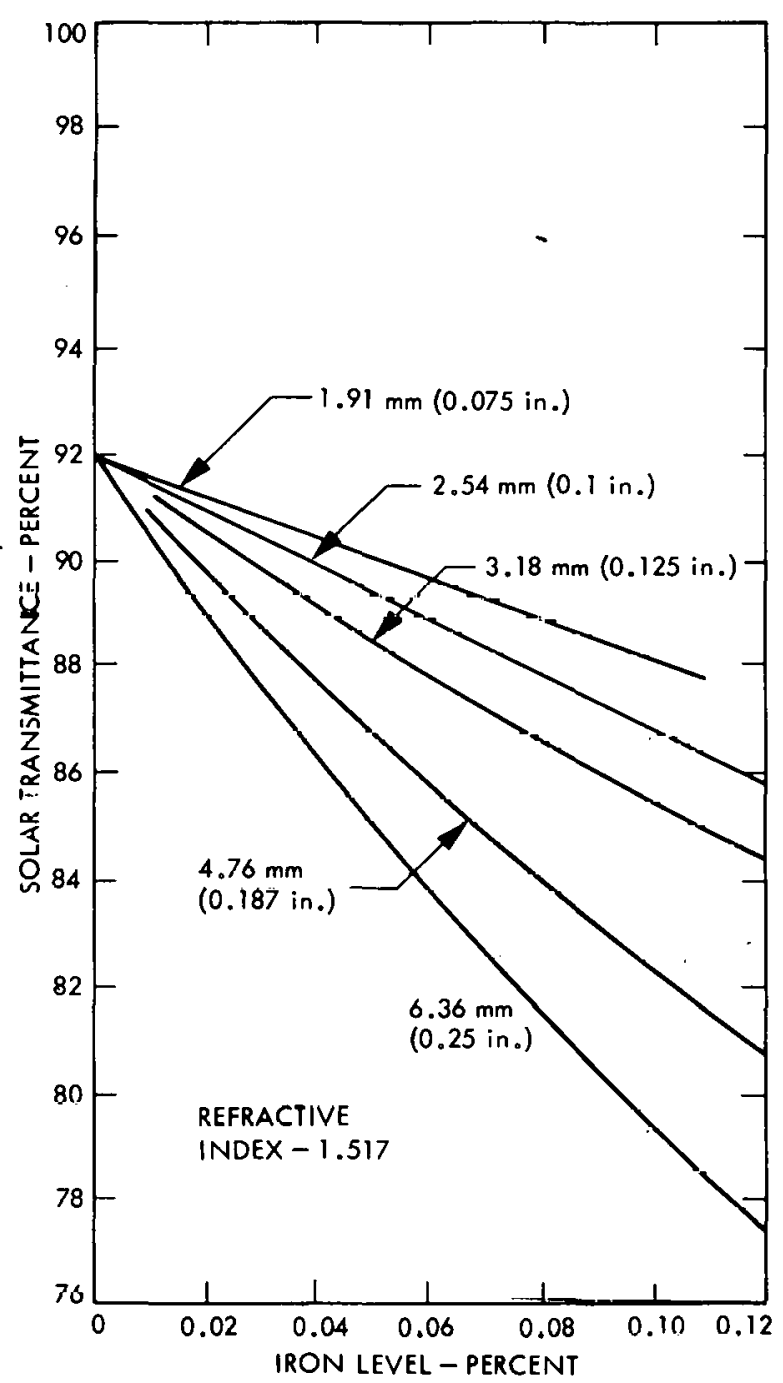

Figure 1. Solar Transmission for Soda-Lime Glass vs. Iron Level (Adapted from Ref. 26)

Table 2. Properties Which Characterize Glass

1. Solar Transmittance

2. Chemical Durability

3. Economics of Production

4. Optical Properties

5. Thermal Expansion

6. Dimensional Stability
7. Thermal Conductivity

8. Mechanical Properties

9. Electrical Properties

10. Density

11. Viscosity

12. Surface Tension 
Table 3. Ranges of Physical Properties of Glass Types Compared to Silicon

\begin{tabular}{|c|c|c|c|c|c|}
\hline Type of Glass & $\begin{array}{c}\text { Specific } \\
\text { Gravity } \\
g / \mathrm{cm}^{3} \\
\left(1 \mathrm{bs} / \mathrm{ft}^{3}\right)\end{array}$ & $\begin{array}{l}\text { Young's } \\
\text { Modulus } \\
10^{3} \mathrm{~kg} / \mathrm{mm}^{2} \\
\left(10^{6} \mathrm{psi}\right)\end{array}$ & $\begin{array}{l}\text { Thermal } \\
\text { Expansion* } \\
\mathrm{cm} / \mathrm{cm}^{\circ} \mathrm{C} \\
\left(\mathrm{x} 10^{-7}\right) \\
\left(\text { in/in }{ }^{\circ} \mathrm{F}\right)\end{array}$ & $\begin{array}{c}\text { Refractive } \\
\text { Index }\end{array}$ & $\begin{array}{c}\text { Poisson's } \\
\text { Ratio }\end{array}$ \\
\hline Soda-Lime & $2.47(154)$ & $\begin{array}{l}6.9-7.1 \\
(10-10.2)\end{array}$ & $\begin{array}{c}85-93.6 \\
(47.2-52.0)\end{array}$ & $1.51-1.52$ & $0.22-0.24$ \\
\hline Aluminosilicate & $\begin{array}{c}2.45-2.64 \\
(145.8-157.2\end{array}$ & $\begin{array}{c}7.3-8.9 \\
(10.3-12.7)\end{array}$ & $\begin{array}{l}42.1-88 \\
(23.4-48.9)\end{array}$ & $1.506-1.547$ & $0.24-0.25$ \\
\hline Borosilicate & $\begin{array}{c}2.13-2.48 \\
(132.8-154.6)\end{array}$ & $\begin{array}{c}5.0-6.9 \\
(7.1-9.8)\end{array}$ & $\begin{array}{c}32-77 \\
(17.8-42.8)\end{array}$ & 1.473 & $0.2-0.23$ \\
\hline $\begin{array}{c}96 \% \text { Fused } \\
\text { Silica }\end{array}$ & $2.18 \quad(135.9)$ & $\begin{array}{c}6.8-6.9 \\
(9.7-9.8)\end{array}$ & $\begin{array}{l}7.6-8 \\
(4.2-4.4)\end{array}$ & 1.458 & 0.19 \\
\hline Fused Silica & $2.2 \quad(137.2)$ & $\begin{array}{c}7.1-7.4 \\
(10.0-10.5)\end{array}$ & $5.6(3.1)$ & 1.459 & 0.16 \\
\hline Silicon & $(149.6)$ & $10.9 \quad(15.5)$ & $(16.6)$ & $\star *$ & 0.22 \\
\hline
\end{tabular}

*over the range 0 to $300^{\circ} \mathrm{C}$ or -18 to $572{ }^{\circ} \mathrm{F}$.

$* *$ Opaque in the visible range.

Source: Corning Glass Works 
Table 4. Range of Physical Properties of Glass

\begin{tabular}{|c|c|}
\hline Property & Range \\
\hline Density $\left(\mathrm{g} / \mathrm{cm}^{3}\right)$ & $2.13-5.42$ \\
\hline Color & Clear to multicolors \\
\hline Index of Refraction & $1.458-1.560$ \\
\hline $\begin{array}{l}\text { Young's Modulus } \\
\mathrm{kg} / \mathrm{m}^{2}\end{array}$ & $5000-12,111111$ \\
\hline Poisson's Ratio & $.0 .16 \sim 0.28$ \\
\hline Knoop Hardness & $363-593$ \\
\hline $\mathrm{KHN}_{100}$ & . \\
\hline $\begin{array}{l}\text { Log Resistivity } \\
\text { ohm-cm }\left(25^{\circ} \mathrm{C}\right)\end{array}$ & $12.4-20.3$ \\
\hline $\begin{array}{l}\text { Dielectric Constant at } 1 \mathrm{MHz},\left(20^{\circ} \mathrm{C}\right) \\
\text { Viscosity }\end{array}$ & $3.8-15.0$ \\
\hline Strain Point $\left({ }^{\circ} \mathrm{C}\right)$ & $340-956$ \\
\hline Aluteal Point $\left({ }^{\circ} \mathrm{C}\right)$ & $363-1084$ \\
\hline $\begin{array}{l}\text { Softening Puinl }\left({ }^{\circ} \mathrm{C}\right) \\
\text { Working Point }\left({ }^{\circ} \mathrm{C}\right)\end{array}$ & $\begin{array}{l}600-1580 \\
862-1252\end{array}$ \\
\hline
\end{tabular}

Note: Viscosity is very important during glass manufacturing. For complete definitions see the glossary. Briefly, the working range is the viscosity at which glass is easily formed. The softening point is where the glass w111 say appleciably under its own weight. The annealing point is the temperature at which locked-up stresses can be relieved. The strain point is where the glass becomes rigid. 
Table 5. Comparative Analysis and Properties of Specific Representative Glasses with Respect to Silicon

\begin{tabular}{|c|c|c|c|c|c|c|c|c|c|}
\hline \multirow[b]{2}{*}{ Type of Glass } & \multicolumn{7}{|c|}{ Analysis, Percent by Weight } & \multirow{2}{*}{$\begin{array}{l}\text { Softening } \\
\text { Temp. }{ }^{\circ} \mathrm{C}\end{array}$} & \multirow{2}{*}{$\begin{array}{l}\text { Coefficient } \\
\text { of } \\
\text { Expansions } \\
\left({ }^{\circ} \mathrm{C}\right)^{-1} \times 10^{-7}\end{array}$} \\
\hline & $\mathrm{SiO}_{2}$ & Modifiers & $\mathrm{Al}_{2} \mathrm{O}_{3}$ & $\mathrm{~B}_{2} \mathrm{O}_{3}$ & $\mathrm{~Pb} 0$ & $\mathrm{Na}_{2} \mathrm{O}$ & $\mathrm{CaO}$ & & \\
\hline Fused Silica & 99.9 & --- & --- & --- & --- & --- & --- & 1580 & 5.5 \\
\hline $\begin{array}{l}96 \text { percent } \\
\text { Silica } \\
\text { (Vycor) }\end{array}$ & 96.0 & $<0.2$ & --- & 4.0 & -- & $<0.2$ & --- & 1530 & 8.0 \\
\hline Aluminosilicate & & & & & & & & & \\
\hline Typical & 57.7 & 9.5 & $17-25.3$ & $4-7.4$ & --- & 1 & 5.5 & 915 & --- \\
\hline Corning 1720 & 62 & --- & 17 & 5 & --- & 1 & 8 & 915 & 42 \\
\hline Soda-Lime Silica & & & & & & & & & \\
\hline Corning 0080 & 73.6 & --- & $0.6-1.0$ & -- & --- & $16-17$ & $0.3-5$ & 695 & 93.5 \\
\hline Borosilicate & & - & & & & & & --- & --- \\
\hline Corning 7070 & $70-80.5$ & 4.2 & $1.1-2.2$ & $12.9-28$ & 1.2 & $0-1.5$ & 0.1 & 820 & 32.0 \\
\hline Corning 7740 & 81 & --- & $2-2.2$ & 13 & --- & $3.8-4$ & --- & 821 & 32.5 \\
\hline Lead Aikali & $35-63$ & 11.0 & --- & --- & $\begin{array}{c}21- \\
58\end{array}$ & 7.6 & 0.3 & 630 & 89.0 \\
\hline $\begin{array}{l}\text { Lustraglass } \\
\text { ASG-low Iron }\end{array}$ & --- & --- & -- & --- & --- & -- & --- & 780 & 88 \\
\hline Silicon & $100 *^{\circ}$ & 0 & 0 & 0 & 0 & 0 & 0 & $\sim 1350$ & 30 \\
\hline
\end{tabular}

*Silicon 
Table 6. Thermal Properties of Some Specific Giasses*

\begin{tabular}{|c|c|c|c|c|}
\hline \multirow[b]{2}{*}{ Property } & \multicolumn{4}{|c|}{ Corning Glass Works Code Number and Type } \\
\hline & $\begin{array}{c}7940 \\
\text { Fused Silica }\end{array}$ & $\begin{array}{c}7740 \\
\text { Borosilicate }\end{array}$ & $\begin{array}{c}1720 \\
\text { Aluminosilicate }\end{array}$ & $\begin{array}{c}0080 \\
\text { Soda-Lime } \\
\text { Silica }\end{array}$ \\
\hline Viscosity, poise & \multicolumn{4}{|c|}{ Temperature ${ }^{{ }^{\circ}} \mathrm{C}$} \\
\hline $10^{14.5}$ (etrain point). & 956 & 510 & 607 & 473 \\
\hline $10^{13}$ (annealing point) & 1084 & 560 & 712 & 514 \\
\hline $\begin{array}{l}10^{7.6} \text { (softening } \\
\text { point) }\end{array}$ & 1580 & 821 & 915. & 695 \\
\hline $10^{4}$ (working point) & --- & 1252 & 1202 & 1005 \\
\hline 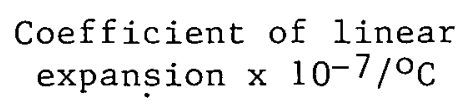 & 5.5 & 33 & 42 & 92 \\
\hline Typical Uses & $\begin{array}{l}\text { High } \\
\text { temperature, } \\
\text { aernspace } \\
\text { windows }\end{array}$ & $\begin{array}{l}\text { Chemical, } \\
\text { baking ware }\end{array}$ & Ignition tube & $\begin{array}{l}\text { Container, } \\
\text { sheet, } \\
\text { plate }\end{array}$ \\
\hline
\end{tabular}

*Data compiled from Properties of Glasses and Glass-Ceramics, Corning Glass Works, Corning, New York, 1973.

tProduccd by vapor deposition.

Thultiply poise by 0.1 to get $\mathrm{N}-\mathrm{s} / \mathrm{m}^{2}$ or $\mathrm{Pa}-\mathrm{sec}$. 
soda-lime which is generally used for windows, tumblers, and other mass-produced glassware. Its relatively high thermal expansion makes it subject to fracture by thermal shock; glasses of lower expansion (such as borosilicates and aluminosilicates) are used for chemical and high temperature applications. These latter glasses have increased amount of boron oxide (13\%) and aluminum oxide (25\%) respectively.

The Corning type 7740 is a general purpose borosilicate glass that has a slightly higher coefficient of thermal expansion (i.e., 32.5) and a higher alkali content than 7070. It has. been found to have greater residual stresses than the $10 \%$ so has not been as widely used. Schott 8330 is quite similar to the 7740 .

General engineering data on glass for solar applications are shown in Figures 2-7. Thermal expansion, conductivity, viscosity, and strength data are plotted. In addition, volume and surface resistivity, power factor and dielectric strength are presented in Figures 8-12.

Some of the more important tests pertaining to glass, taken from ASTM literature are shown in Table 7 . Other information on high transmissivity glass is given in Section IV entitled Glass Performance, Spectral Characteristics.

The wide variability of the data is apparent and the physical properties of glass composition are complex. The two best references for the solar glass designer are Strand (Reference 5) and Corning Glass Works' Properties of Glasses and Glass Ceramics (Reference 1), although many other fine treatises exist.

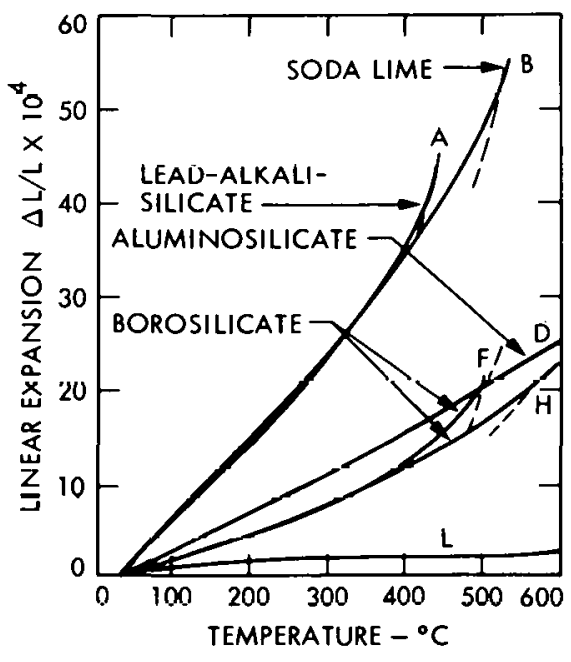

Figure 2. Linear Expansion of Glasses with Temperature (Adapted from Phillips Ref. 32) 


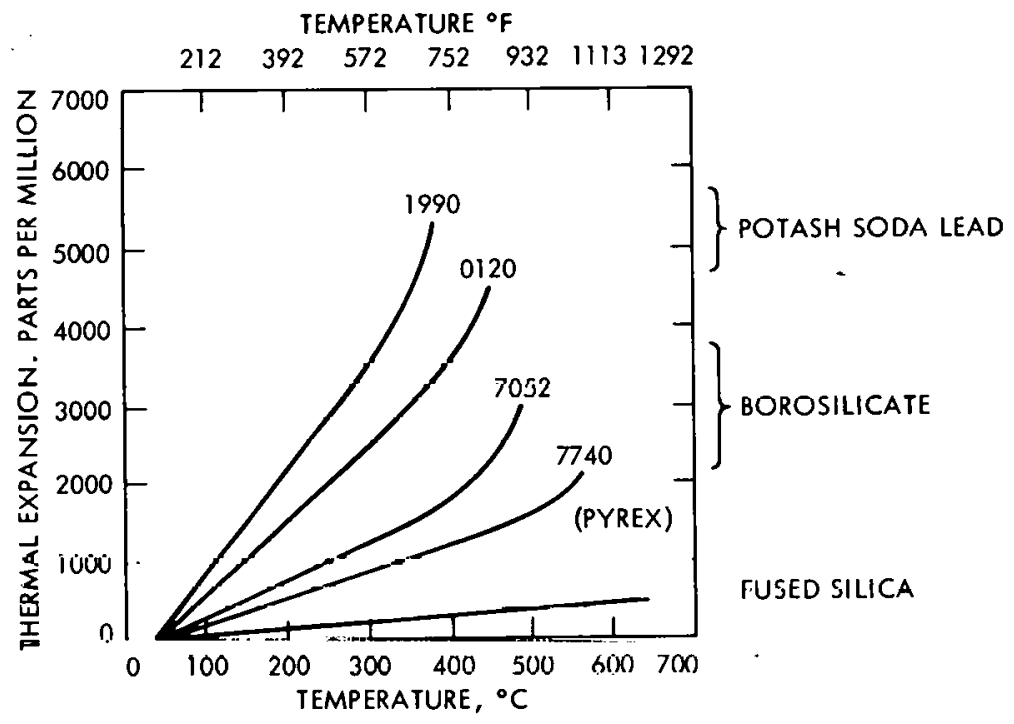

Figure 3. Expansion-Temperature Curves for l'ypical Corning Glasses (Ret, 1)

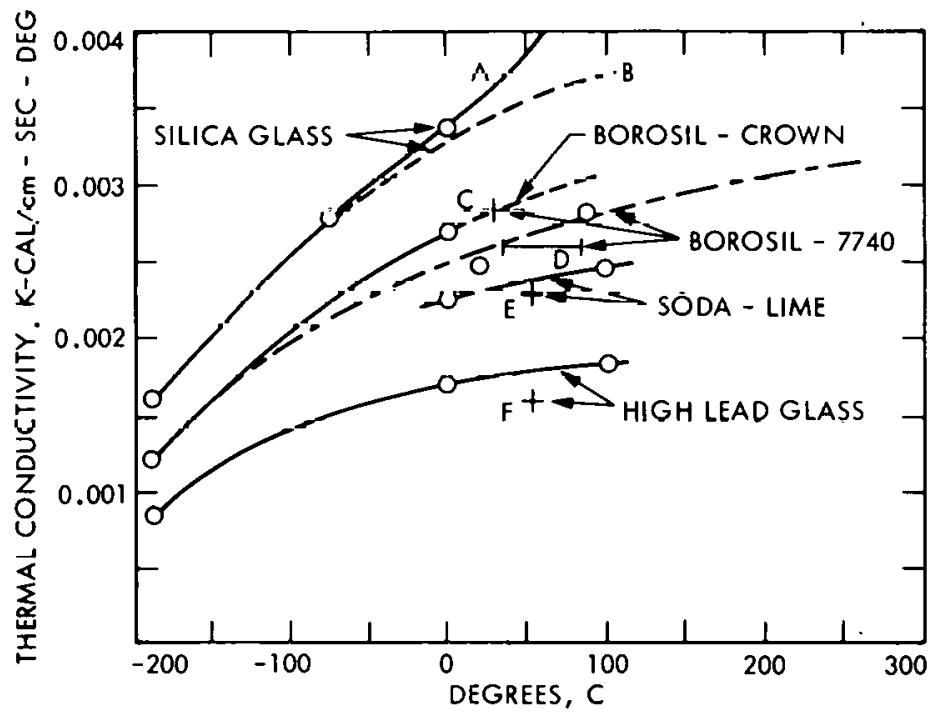

Figure 4. Thermal Conductivity of Corning Glasses (Ref. 11) 


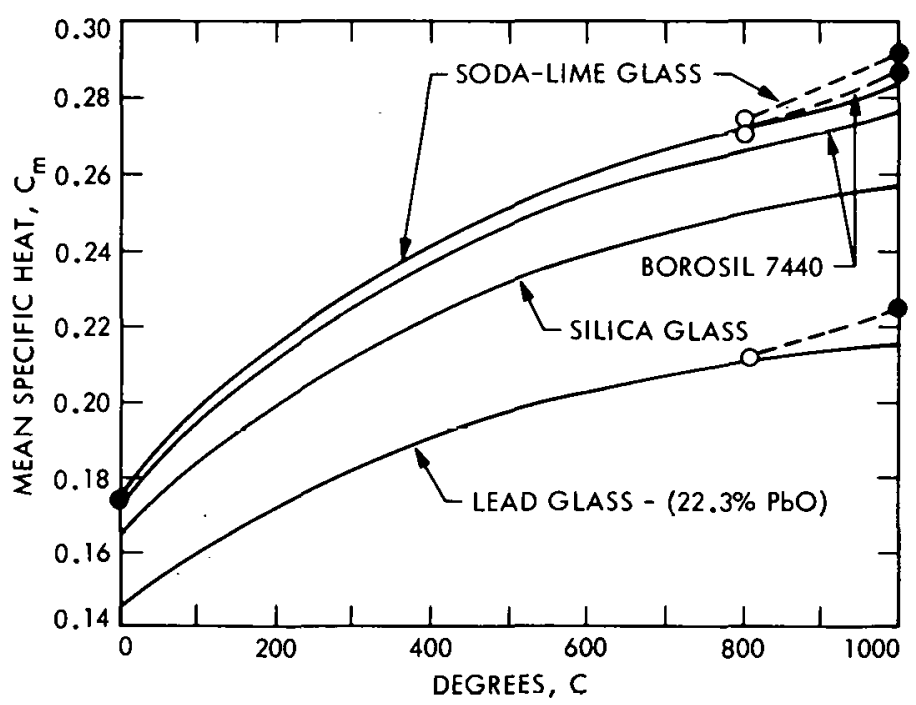

Figure 5. Mean Specific Heat of Corning Classes (Ref. 11)

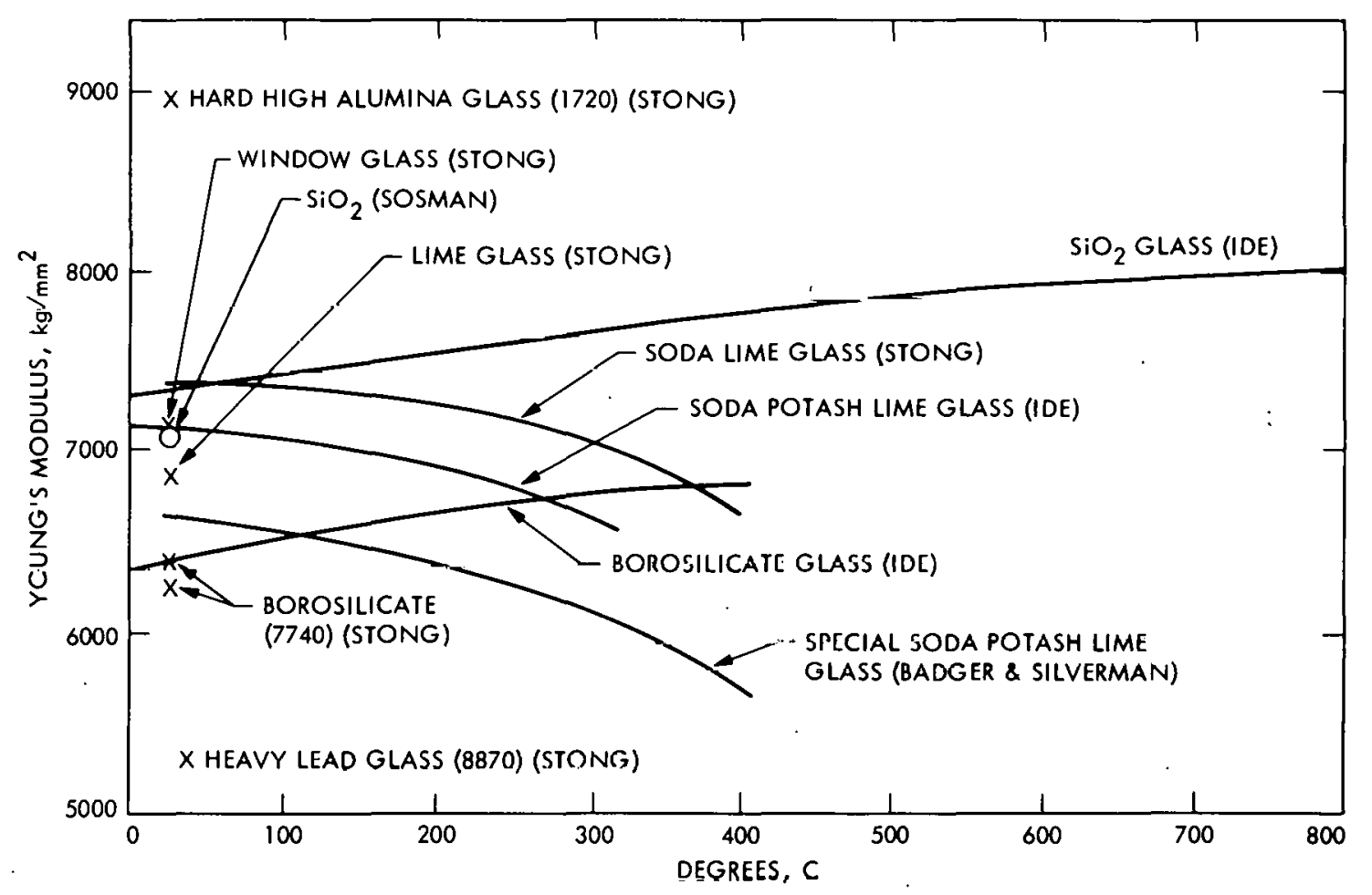

Figure 6. Young's Modulus of Various Glasses (Ref. 11) 


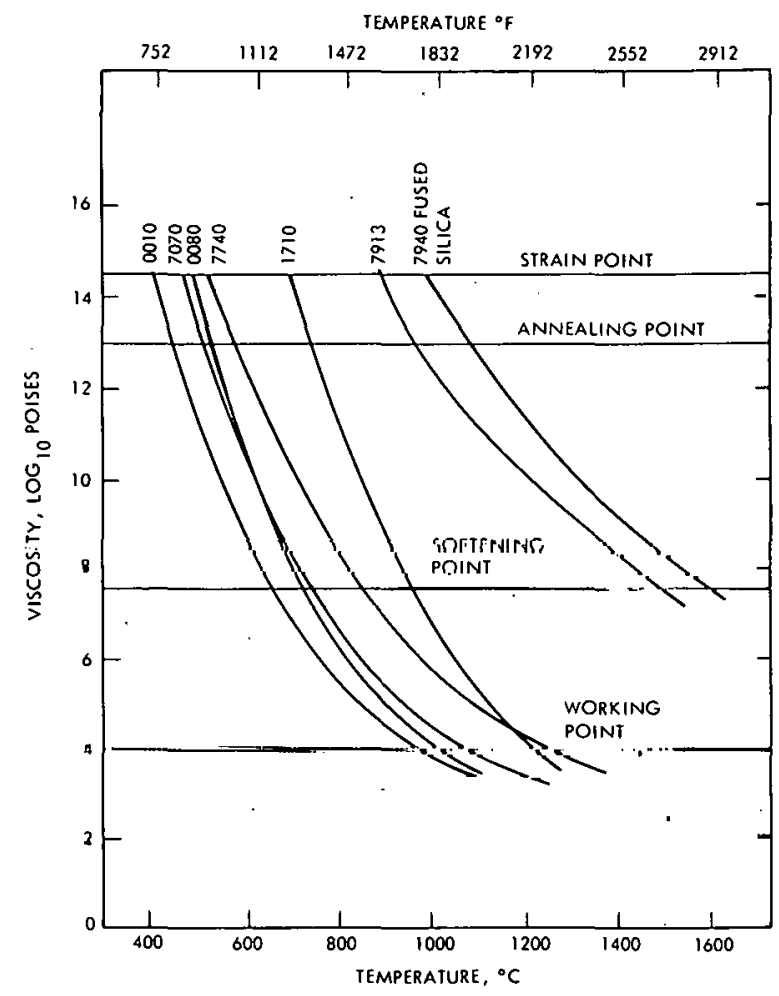

Figure 7. Viscosity - Temperature Curves of Various Corning Glasses (ReI. 1)

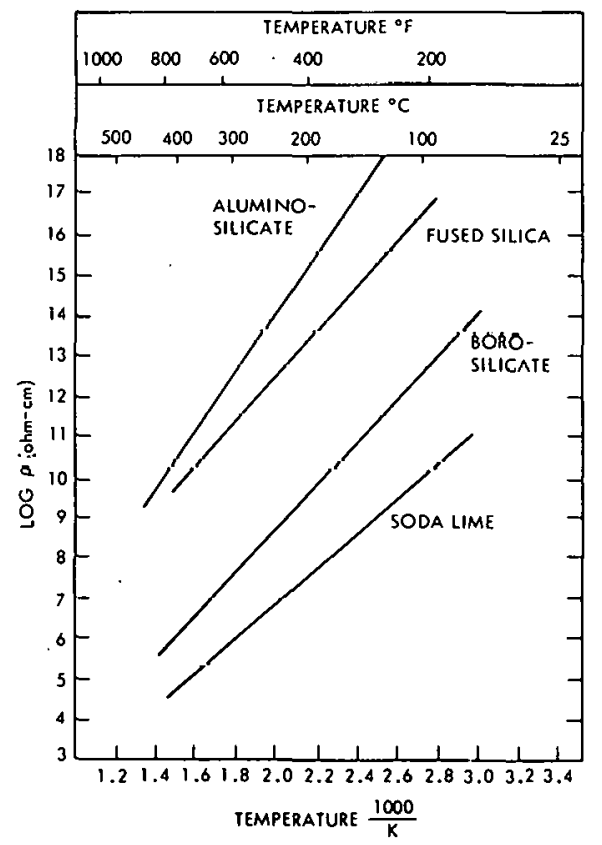

Figure 8. Volume Resistivity for Various Corning Glasses (Ref. 1) 


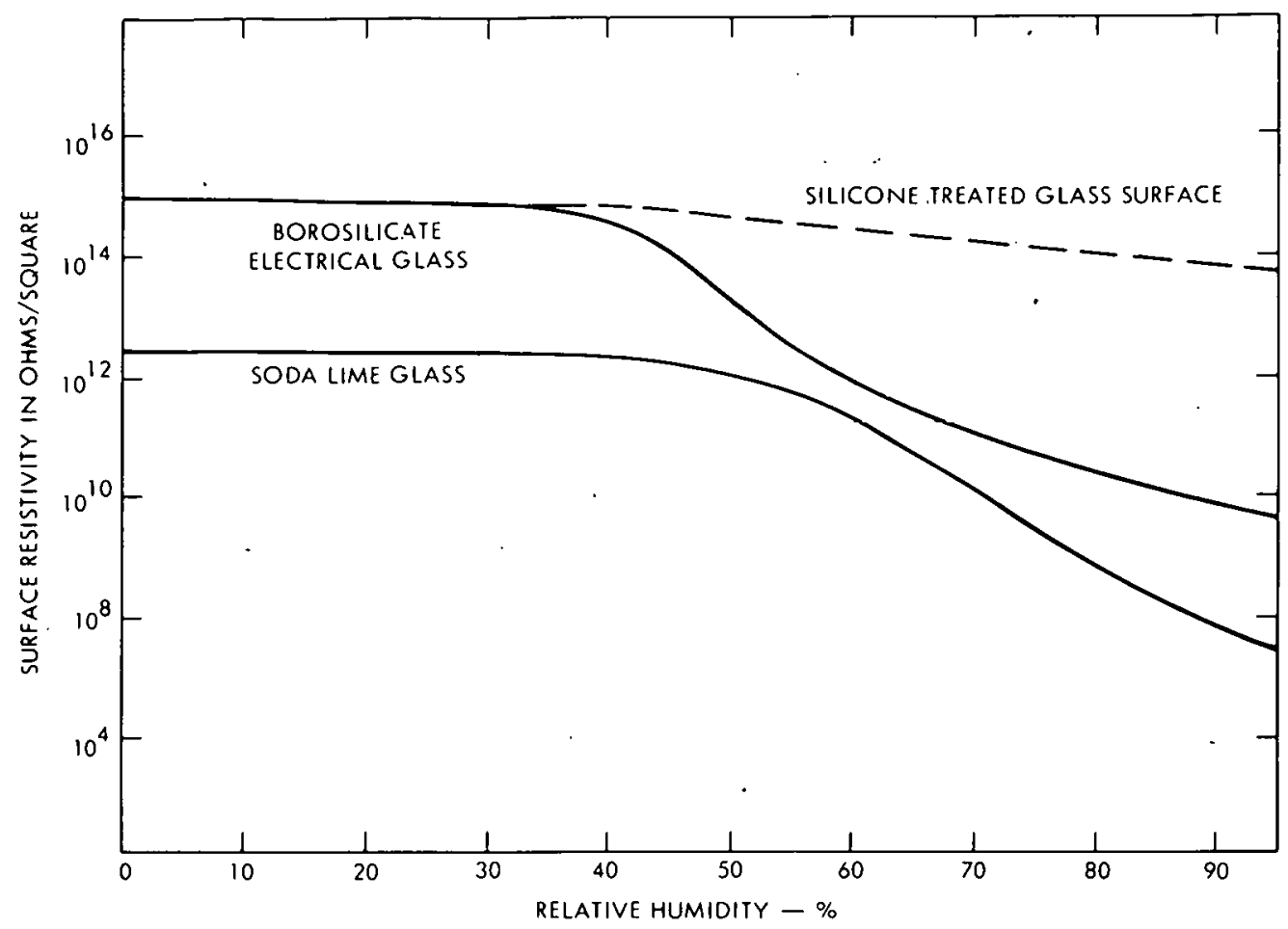

Figure 9. Surface Resistivity of Corning Glasses

vs. Relative Humidity (Ref. 1)

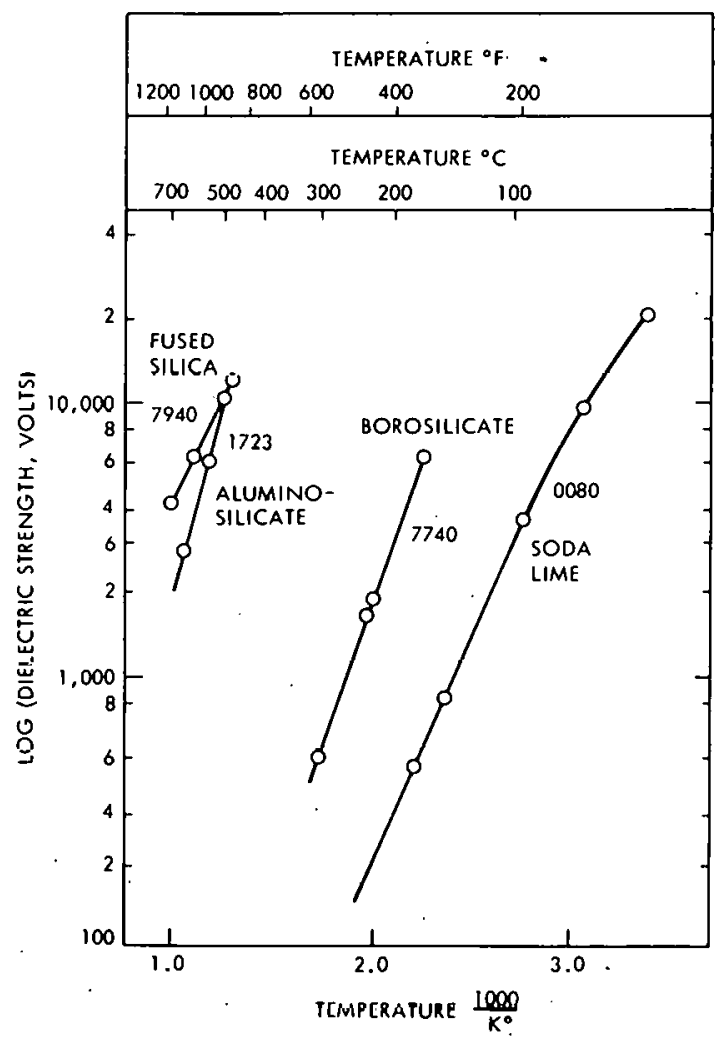

Figure 10. Dielectric Strength vs. Temperature for Corning Glasses (Ref. 2) 


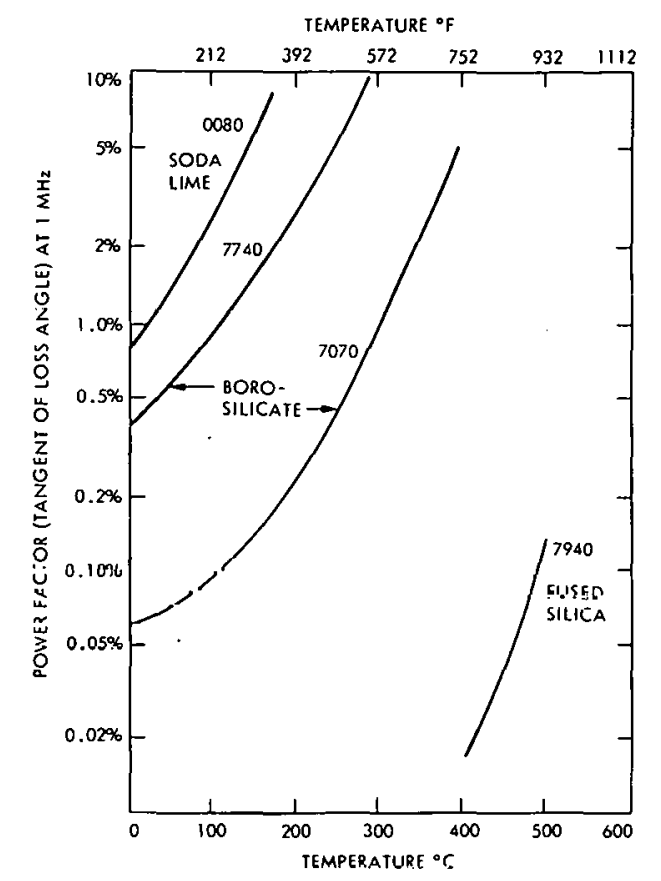

Figure 11. Power Factor vs. Temperature for Corning G1 ass (Ref. 1)

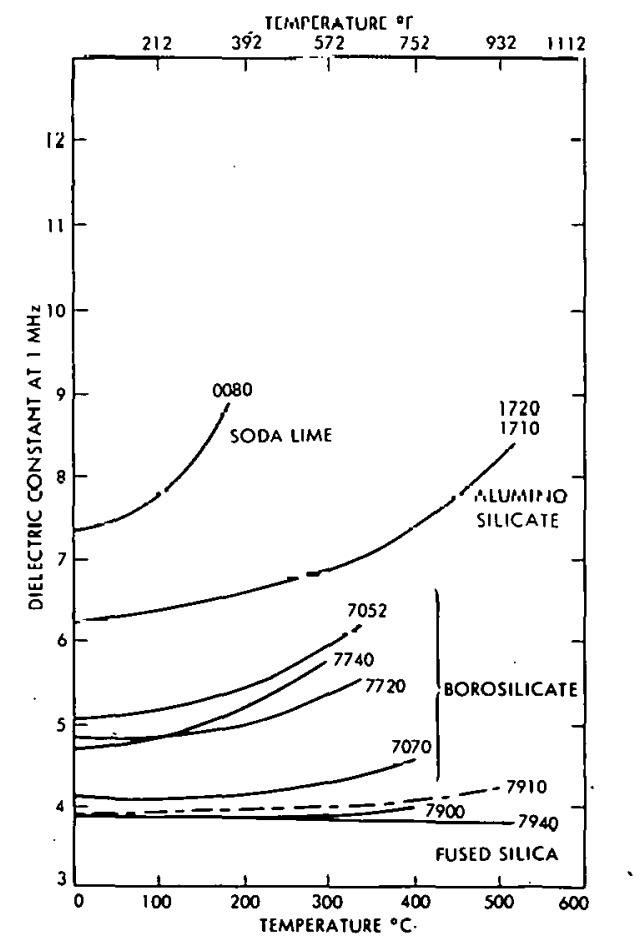

Figure 12. Variation of Dielectric Constant with Glass Temperature for Various Corning Glasses (Ref. 1) 
1. Test for Annealing Point and Strain Point of Glass by Beam Bending, C 598, Vol. 17.

2. Definition of terms relating to Glass and Glass Products, C 162, Vo1. 17.

3. Standard Reference Materials for Glass and Glass Products, Vol. 17.

4. Recommended Practices for Glass Stress Optical Coefficient, C 770, Vo1. 17.

5. Test for Hydrophobic Contamination on Glass by Water Condensation, C 812; Vol. 17 .

6. Test for the Suftening Point of Glass, c 338, Vol. 17.

7. Test for Analyzing Stress in Glass, F 218, Vo1. 17, 43.

8. Test for Young's Modulus, Shear Modulus and Poisson's Ratio for Glass and Glass--Ceramics by Resonance, C 623, Vol. 17.

9. Test for Linear Expansion ... E 228, Vo1. 10, 17, 41, 44.

10. Hydrophobic Contamination Test on Glass by Contact Angle, C 813, Vo1. 17.

\section{COMMERCIAL SOURCES OF GLASS}

A list of the domestic sources of glass compiled as a result of this study is shown in Table 8 . The literature of glass manufacturers and glass processors is very extensive. Therefore, only important sources are listed.

Table 9 shows a list of foreign manufacturers of flat glass. See Reference 25. Sources of foreign glass are not unlimited, however. One glass industry spokesman has stated that their current sources of supply are straining the entire European glass production capability. Therefore, research is needed to determine the extent of future glass sources.

Glass thicknesses of interest in photovoltaic applications are in the range of $0.7 \mathrm{~mm}$ (0.028 in.) to $6.35 \mathrm{~mm}$ (0.25 in.). Typical U.S. suppliers of low-cost soda-lime glass are ASG, PPG, Ford, LOF, and Fourco. Thicknesses and sizes vary with the particular supplier and availability may change with time. Table 10 shows the typical thickness, weight/unit area and maximum size of thin float glass available from one manufacturer. Only photovoltaic thicknesses are included. Table 11 gives the trade names and producers of glass of potential interest to photovoltaic designers. Properties are given in Table 1 . 
Table 8. List of Domestic Glass Manufacturers and Sales Contacts

\section{Manufacturers}

ASG Industries, Inc.

P.0. Box 929

Kingsport, TN 37662

Attn: W. Cooke

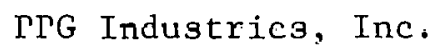
One Gateway Center

Pittsburg, PA 15222

Attn: C.R. Frownfelter

Ford Motor Company

Glass Division

3000 Renaissance Center

P.O. Box 43343

Detroit, MI 48243

Attn: P. Bender

Libby Owens Ford Company

Technical Center

1701 F. R̈rnadway

Toledo, OH 43605

Attn: H.R. Swift

CE Glass Division

825 Hylton Kd.

Pennsarken, NJ 08110

Attn: T. Martin
Fourco Glass Company

P. O. Box 2230

Clarksburg, WV 26301

Attn: J. McVaney

Guardian Industries Corp: $43043 \mathrm{~W}$. Nine Mile Road

Northville, MI 48167

Attn: D. Wiley

Corning Glass Works

Corning, NY 14830

Attn: A.F. Shoemaker

Jena Glaswerk Schott \& Gen. Inc.

11 East 26th Street

New York, NY 10010

Attn: J. Schrauth

Armor World Wide Glass Company

9401 Ann Sireet

Santa Fe Springs, CA 90670

Attn: A. Krieger

(Sunadex ${ }^{R}$ and Solartex ${ }^{R}$ )

Northwestern Industries, Inc.

2501 West Commodore Way

Seattle, WA 98199

Attn: T. McQuade

(Sunadex ${ }^{\mathrm{R}}$ and Solartex ${ }^{\mathrm{R}}$ ) 
Table 9. List of Foreign Manufacturers of Flat Glass (Ref. 25)

Nippon Sheet Glass Co. Ltd.

8-4-Chome, Doshomachi

Nigashi-Ku, Osaka, Japan

Central Glass Co. Ltd.

Kowa-Hitotsubashi Bldg., 7,

Kanada-Nishiricho 3 Chome

Chiyoda-Ru Tokyo 101, Japan

Saint-Gobain Industries

62 Boulevard Victor-Hugo

P.O. Box 124

92209 Neuilly-Sur-Seince, France

Exprover S.A.,

Parc Seny, Rue Charles Lemaire, 1

Boite No. 7, 1160 Brussels, Belgium

Pilkington Aci Limited

470 Collins Street

Melbourne, Victoria

3000 , . Australia

Flachglas Ag Delog-Detag

650 Gelsenkirchen-Rot thausen,

Auf der Reihe 2,

Postfach 669, Germany

Australian Consolidated Ind. Ltd.

550 Bourke Street

Melbourne, Victoria

3000 , Australia

Erste Osterreichische

Mashinglasind, $\mathrm{Ag}$

2345 Brunn/Gebirge,

P.0. Box 9,

Austria

Pilkington Glass Ltd.

101 Richmond Street. West

Toronto M5H IV9, Ont.; Canada

Pilkington Brothers Ltd.

SL. Helens, Merseyside, Wa10 3TT

England
Asahi Glass Co. Ltd.

1-2, Marunoichi 2-Chome,

Chiyoda-Ku, Tokyo 100, Japan

BSN-Gervais Danone

Boussois Souchon Neuvesel

22, Bd Malesherbes

Paris 8, France

Jena Glaswerk Schott \& Gen., Inc.

11 East 26th Street

New York, NY 10010

Glaverbel S.A.

Chaussee de la Hulpe 166

B-1170

Brussels, Belgium

Glaceries de St. Roch S.A.

Exprover S.A.

Avenue Louis 430

B- 1050

Brussels, Belgium

Glaces de Boussoi.s

22 Boulevard Malesherbes

Paris 8 , France

Compagnie de Saint Gobain

Fabrica Pisana

Via Aurelia 非 1

56100

Pisa, Italy

Cristaleria Espanola S.A.

Almagro 42

Madred 4, Spain

Sk1o Union

N.P.

Teplice - Retenice

Czechoslovakia

Vidrierias de Uodio S.A.

Carmen 20

Llodio, Alava, Spain 
Table 10. Availability of Float Glass from One Manufacturer

\begin{tabular}{|c|c|c|c|c|}
\hline \multirow[b]{2}{*}{$\begin{array}{c}\text { Type of } \\
\text { Glass }\end{array}$} & \multicolumn{2}{|c|}{ Thickness } & \multirow{2}{*}{$\begin{array}{c}\text { Weight/. } \\
\text { Unit Area } \\
\mathrm{kg} / \mathrm{m}^{2} \\
\left(1 \mathrm{~b} / \mathrm{ft}^{2}\right)\end{array}$} & \multirow{2}{*}{$\begin{array}{c}\text { Maximum Size } \\
\text { Standard } \\
\mathrm{m} \times \mathrm{m} \\
\text { (inches } \mathrm{x} \text { inches) }\end{array}$} \\
\hline & $\begin{array}{c}\text { Nominal } \\
\mathrm{mm} \\
\text { (inches) }\end{array}$ & $\begin{array}{c}\text { Tolerance } \\
\text { mn } \\
\text { (inches) }\end{array}$ & & \\
\hline \multirow{2}{*}{ Clear Float } & $\begin{array}{l}3.175 \\
(1 / 8)\end{array}$ & $\begin{array}{l} \pm 0.79 \\
( \pm 1 / 32)\end{array}$ & $\begin{array}{r}8.02 \\
(1.64)\end{array}$ & $\begin{array}{l}1.52 \times 2.03 \\
(60 \times 80)\end{array}$ \\
\hline & $\begin{array}{l}6.35 \\
(1.4)\end{array}$ & $\begin{array}{l} \pm 0.79 \\
( \pm 1 / 32)\end{array}$ & $\begin{array}{l}16.03 \\
(3.28)\end{array}$ & $\begin{array}{l}3.1 \times 5.08 \\
(122 \times 200)\end{array}$ \\
\hline
\end{tabular}

NOTE: Other thicknesses up to $25.4 \mathrm{~mm}$ ( 1.0 inch) are available.

Table 11. Trade Names and Suppliers of Glass Materials

Glass Trade Designation

Glass Supplier

ASG Sunadex

ASG Tustraglass

Corning 1940 Fused Śilica

Corning 7740 Borosilicate

Corning 7070 Borosilicate

Corning 7059 Borosilicate

Corning 0211 Microsheet

Cupulny 0080 3uda-Lime

Corning 1720 Aluminosilicate

Corning 1723 Aluminosilicate

Corning 8871 Potash Lead

Fourco Clearlite

General Electric 776 Borosilicate

General Electric 008 Soda-Lime

General Electric 351

Innotech IP 530

Owens-Illinois KG-33 Borosilicate

Owens-Illinois ES-l Borosilicate

Owens-I11inois EE-5

Owens-I1linois R-6 Soda-Lime

PPG Float

PPG NESA

Schott 8330 Borosilicate
ASG Industries, Inc., Kingsport, TN

AȘG Industries, Inc., Kingsport, TN

Corning Glass Works, Corning, NY

Corning Glass Works, Corning, NY

Corning Glass Works, Corning, NY

Corning Glass Works, Corning, NY

Corning Glass Works, Corning, NY

Corning Glasз Worlco, Corning, NY

Corning Clàss Works, Corning, NY

Corning Glass Morks, Corning, NY

Corning Glass Works, Corning, NY

Fourco Glass Co., Clarksburg, WV

General Electric Co., Richmond Heights, OH

General Electric Co., Richmond Helghrs, $\mathrm{OH}$

General Electric Co., Richmond Heights, $\mathrm{OH}$

Innotech Corp., Norwalk, CT

Owens-Illinois, Inc., Toledo, $\mathrm{OH}$

Owens-Illinois, Inc., Toledo, $\mathrm{OH}$

Owens-Illinois, Inc., Toledo, $\mathrm{OH}$

Owens-Illinois, Inc., Toledo, $\mathrm{OH}$

PPG Industries, Inc., Pittsburgh, PA

PPG Industries, Inc., Pittsburgh, PA

Schott Optical Glass, Tnc., Duryea, PA 
E. COSTS OF GLASS

Various factors should be considered when investigating glass. Three of these factors are considered briefly below, namely:

(1) Type of glass: sheet, float or plate.

(2) Batch formulation.

(3) Energy consumed in glass manufacturing.

The cost of glass varies with the type of glass. The costs of glass purchased in large quantities have been summarized previously and are shown in Table 12. (See References 7, 25, and 28.) Basic prices in quantaties of the order of one million to 10 million square feet vary from $\$ 3.23$ to $\$ 23.13$ per square meter ( $\$ 0.30$ to $\$ 2.15$ per square foot, 1978 dollars). Note that the highest price listed $\left(\$ 2.15 / \mathrm{ft}^{2}\right)$ was for low-iron glass which has the highest transmittance of solar energy. However, the majority of the glass produced by the glass industry is approximately $3 \mathrm{~mm}$ ( 0.11 inch) thick, and consequently it is cheapest. Glass of thinner or thicker dimensions will usually cost more. The wide range of prices depends upon the details of production and marketing within the glass industry and insight into the various aspects are given later in the discussion below.

Estimates of low-volume glass costs from one manufacturer for several thicknesses iron content, and state of temper are shown in Figure 13 . See Reference 33. The data have been normalized to $\$ / \mathrm{m}^{2}$ and refer to 1978 dollars.

The thicknesses of interest for solar photovoltaic applications are between $3.175 \mathrm{~mm}$ (0.125 in.) and $6.35 \mathrm{~mm}(0.250 \mathrm{in.)}$. If the glass is too thin, the breakage is unacceptable; if too thick, the glass absorbs too much sunlight which results in reduced solar cell output. Panel costs from another source (Reference 34) are shown in Table 12 for the three types of photovoltaic glass, namely soda-lime, low-iron tempered glass and borosilicate.

Table 14 gives the typical prices in 1980 dollars for two types of commonly used low-iron ASG glass. In truckload quantities, at the Midwest factory, the price per square area varies primarily with cutting costs. For example, Solartex $5 \mathrm{~mm}$ thick, costs $\$ 5.3 / \mathrm{m}^{2}-\$ 6.56 / \mathrm{m}^{2}$ at the factory depending upon the cutting needed.

In small quantities, on the West or East coast, prices for small amounts $\left(\sim 10^{3} \mathrm{ft}^{2}\right)$ are $\cong \$ 8.6 / \mathrm{m}^{2}-\$ 10.98 / \mathrm{m}^{2}$. The higher prices reflect shipping costs and other costs. Whereas the Sunadex is very low-iron glass, the price differential is much higher than Solartex, with slightly more iron content. This explains the greater public purchases of the latter glass.

As mentioned previously, the actual costs and availability of glass are influenced by a number of factors besides type, volume, and thickness, such as unused industry capacity, batch formulation, acceptable tolerances and other factors. Glass manufacturing is an energy-intensive process which depends strongly on high-volume production to make low-priced products. The effects of product quality and shape, furnace size, type, and pull rates, glass type, and 

Table 12. Typical Large Volume Glass Costs
(Adopted from Ref. 25)

\begin{tabular}{|c|c|c|c|c|c|c|}
\hline \multirow[b]{2}{*}{ Manufacturer } & \multirow[b]{2}{*}{ Process } & \multirow[b]{2}{*}{ Composition } & \multicolumn{2}{|c|}{ Thickness } & \multicolumn{2}{|c|}{$\begin{array}{l}\text { Approximate Cost } \\
\text { Per Sq. Ft.* }\end{array}$} \\
\hline & & & Tested & Possible & $1: \mathrm{MSq} \cdot \mathrm{Ft}$ & $>10 \cdot \mathrm{M} \mathrm{Sq} \cdot \mathrm{Ft}$. \\
\hline 4 & $\begin{array}{l}\text { Lo-Iron } \\
\text { Float }\end{array}$ & Soda-Lime & 0.125 & & 0.31 & 0.31 \\
\hline 1 & $\begin{array}{l}\text { Lo-Iron } \\
\text { Twin Cround }\end{array}$ & Soda-Lime & & $>4 \mathrm{~mm}$ & 1.30 & \\
\hline$\underline{2}$ & Float & Soda-Lime & 0.125 & & 0.50 & \\
\hline 2 & $\begin{array}{l}\text { Lu-Iroul } \\
\text { Twin Ground }\end{array}$ & Soda-Lime & & & 1.30 & \\
\hline 7 & Fusion & Aluminosilicate & 0.110 & $>0.020$ & $0.65-0.80$ & \\
\hline 8 & Fusion & Aluminosilicate & 0.090 & & $0.65-0.80$ & \\
\hline 9 & Fusion & Aluminosilicate & 0.060 & & $0.45-0.70$ & \\
\hline 14 & fusion & $\begin{array}{l}\text { Lime } \\
\text { Borosilicate }\end{array}$ & 0.045 & & 1.40 & 0.45 \\
\hline 3 & Float & Soda-Lime & 0.125 & $>0.105$ & 0.40 & \\
\hline 15 & Float & Soda-Lime & & $>0.085$ & 1.00 & \\
\hline 6 & T.n-Trnn & Soda-Lime & 0.125 & $>0,060$ & 2.15 & $0.60-0.65$ \\
\hline
\end{tabular}

*1978 Costs 


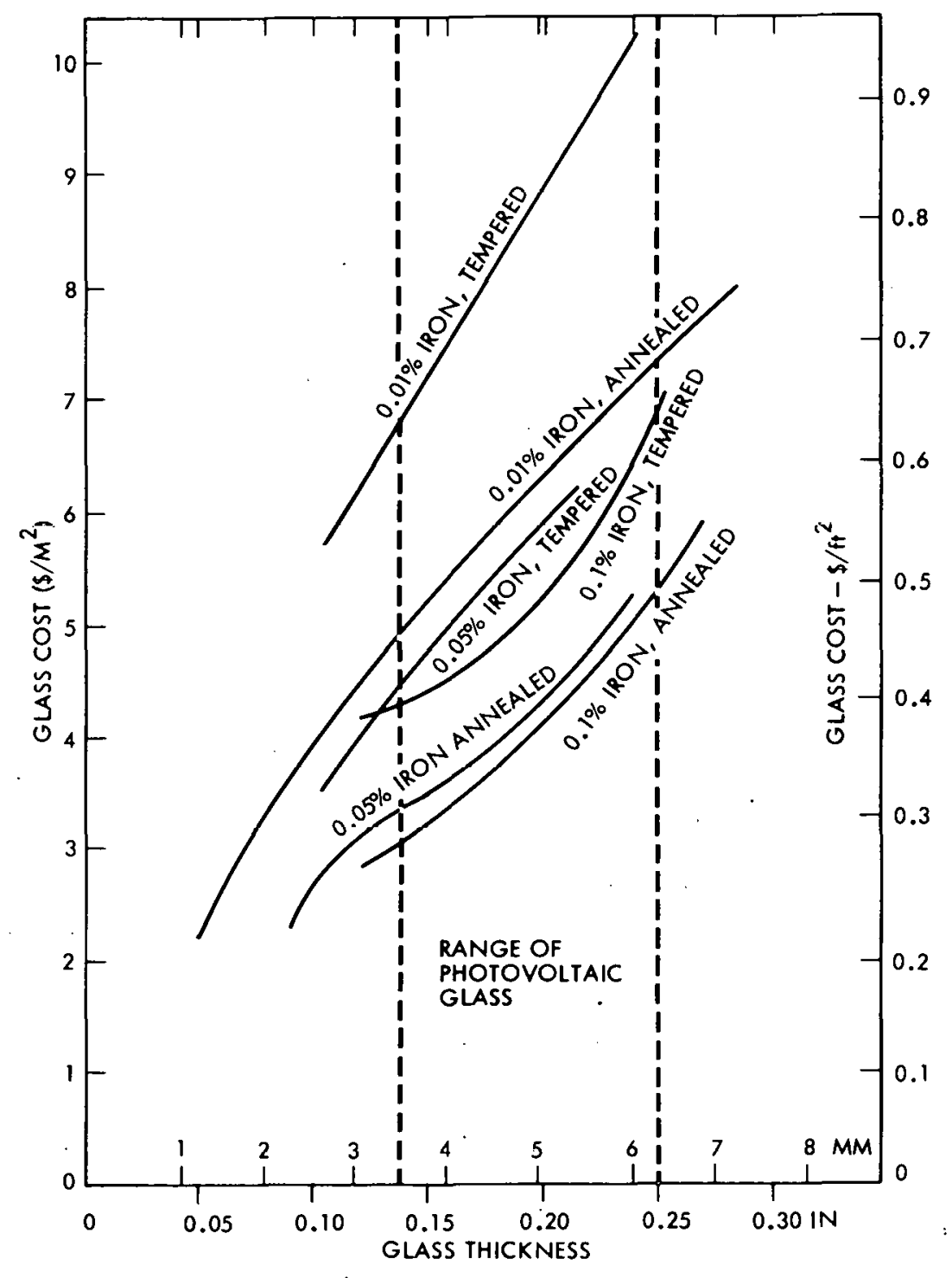

Figure 13. Glass Cost Data (Ref. 33) (in 1978 Dollars) 
Table 13. Typical Prices for Medium Thickness Glass (Ref. 34)

\begin{tabular}{|l|c|c|}
\hline \multirow{2}{*}{ Type of Glass } & \multicolumn{2}{|c|}{ Panel Cost } \\
\cline { 2 - 3 } & $\$ / \mathrm{m}^{2}$ & $\$ / \mathrm{ft}^{2}$ \\
\hline Soda-Lime & 3.15 & 0.30 \\
Low-Iron Tempered Glass & 7.50 & 0.70 \\
Borosilicate & $5-15$ & $0.46-1.39$ \\
\hline
\end{tabular}

Table 14. Typical Prices for Low-Iron Soda-Lime Glass (1980 Prices)

\begin{tabular}{|c|c|c|c|}
\hline \multirow[b]{2}{*}{ Type of Glass } & \multirow{2}{*}{$\begin{array}{c}\text { Thickness } \\
\text { mm } \\
\text { (in.) }\end{array}$} & \multicolumn{2}{|c|}{$\begin{array}{l}\text { Prices tor Given Quantities } \\
\qquad / 1 \mathrm{~m}^{2}\left(\$ / I L^{2}\right)\end{array}$} \\
\hline & & $\begin{array}{c}\text { Large } \\
(>4 n k \text { 1hs) }\end{array}$ & $\begin{array}{c}\text { Sma11 } \\
(<<4 \cap k \text { 1hs })\end{array}$ \\
\hline $\begin{array}{l}\text { ASG Solartex } \\
20.05 \% \text { Iron }\end{array}$ & $\begin{array}{l}3 \\
(0.118) \\
5 \\
(0.197)\end{array}$ & $\begin{array}{l}4.9-8.9 \\
(0.46-0.83) \\
5.3-0.56 \\
(0.49-0.61)\end{array}$ & $\begin{array}{l}8.6 \\
(0.80) \\
10 . \dot{9} 8 \\
(1.02)\end{array}$ \\
\hline $\begin{array}{l}\text { ASG Sunadex } \\
\text { U. U1\% Iron }\end{array}$ & $\begin{array}{l}3 \\
(0.118) \\
5 \\
(0.197)\end{array}$ & $\begin{array}{c}7.6-10.4 \\
(0.71-0.97) \\
10.1-12.8 \\
(0.94-1.19)\end{array}$ & $\begin{array}{c}11.4 \\
(1.06) \\
14.53 \\
(1.35)\end{array}$ \\
\hline
\end{tabular}


secondary (postforming) operations on production volume costs, or energy input, are important. The parameters are not independent but combine to create a complex set of factors unique to a particular product, tank, or plant.

Product quality (such as optical perfection) is an important factor for most glass products. Very few bubble-containing-glass products could be sold for windows; yet, if consumers would accept lower quality products, slightly higher production rates could result in lower prices. The dimensional and optical quality requirements for container glass are low compared to those for other types of glass. This is one of the reasons why the price per metric ton of container glass shipped is less on the order of 70 percent less than that of flat glass.

Product shape and size also affect the manufacturing cost per unit weight of glass. Complex shapes are more costly to manufacture per unit weight of glass than simple shapes because the equipment required is complex. Any shape that can be formed continuously rather than by intermittent pressing or blowing can usually be made at lower cost. Similarly, the greater the thickness of the part, assuming equal processing difficulty, the lower is the unit-weight manufacturing cost (but not necessarily selling price). Very thin glass can be more difficult to form, and is particularly difficult to handle and ship, so costs are commonly higher than those of higher volume standard-size items of the same glass.

Lowest possible prices of uncoated, untempered sheet and float glass are compiled in Table 15; the Department of Commerce data are based on "shipment value" and are reported to reflect manufacturers' wholesale prices, which are considerably lower than retail prices. The data is in 1975 dollars.

Note that average sheet-glass prices have gone up while average float- and plate-glass prices have gone down, reflecting the change in process technology. Some of the thicker float glass being produced today is coated for esthetic purposes, or to control heat transfer (e.g., windows). A large amount of flat glass is thermally tempered, and used in special applications, such as automotive side windows and patio doors. Tempered glass is currently priced two to three times higher than ordinary annealed glass.

The total quantity of flat glass produced in 1974 was about $2.6 \times 10^{8} \mathrm{~m}^{2}$ $\left(2.8 \times 10^{9} \mathrm{ft}^{2}\right)$, for which about $2 / 3$ was produced by the float process. The projected market of $5 \times 10^{6} \mathrm{~m}^{2} / \mathrm{yr}$ for photovoltaic arrays in 1985 could be accommodated by only a 2 percent increase in production capability.

The type of glass affects processing costs from the standpoint of batch material costs, refractory wear (i.e., tank life), fuel consumption (melting temperature), and production rate (longer melting time). Borosilicate glasses are considered to be very difficult to melt compared to soda-lime-silica glasses for all the above reasons. Fuel consumption may be 50 percent higher because of reduced throughput and higher temperatures. Raw material costs are typically two to four times those for conventional soda-lime-silica glasses, depending on the glass composition (i.e., property requirements). $\mathrm{B}_{2} \mathrm{O}_{3}, \mathrm{~K}_{2} \mathrm{O}, \mathrm{Li}_{2} \mathrm{O}, \mathrm{Pb} 0, \mathrm{ZnO}$, and many other oxide components of "special" glasses are available only as refined or synthesized compounds which are much more costly than naturally occurring minerals such as sand, feldspar, and limestone used in soda-lime-silica glasses. An example is shown below to illustrate that the specially refined ingredients of a glass 
Table 15. Lowest Possible Prices for Annealed Flat Glass (Ref. 28)

\begin{tabular}{|c|c|c|c|c|}
\hline \multirow[b]{3}{*}{ Glass Description } & \multicolumn{4}{|c|}{ Price, $\$ / \mathrm{m}^{2}\left(\$ / \mathrm{ft}^{2}\right)$} \\
\hline & \multicolumn{3}{|c|}{$\begin{array}{c}\text { Calculated From U.S. Department Commerce } \\
\text { Statistics Published in Current Industrial } \\
\text { Reports, Flat Glass (a) }\end{array}$} & \multirow{2}{*}{$\begin{array}{c}\text { Local } \\
\text { Distributor } \\
\text { (Retail) } \\
\text { January, } 1976\end{array}$} \\
\hline & 1973 & 1974 & $\begin{array}{c}\text { First Half } \\
1975\end{array}$ & \\
\hline Sheet Glass, average & $1.45(0.135)$ & $1.58(0.147)$ & $1.75(0.163)$ & --- \\
\hline single strength $(3 / 32$ in. $)$ & --- & --- & $1.68(0.156)$ & $3.98(0.37)$ \\
\hline Double strength ( $1 / 8$ in.) & --- & --- & $1.82(0.169)$ & $5.06(0.47)$ \\
\hline Thin and tinted & --- & -- & $3.10(0.288)$ & --- \\
\hline Plate and Float Glass, average & $3.31 \quad(0.308)$ & $3.16(0.294)$ & $2.84(0.264)$ & --- \\
\hline Not over $1 / 8 \mathrm{in}$. & --- & --- & $2.04(0.190)$ & $3.77(0.35)$ \\
\hline $1 / 8$ to $1 / 4$ in. & --- & --- & $3.50(0.325)$ & --- \\
\hline Over $1 / 4$ in. & --- & --- & $5.11(0.475)$ & --- \\
\hline
\end{tabular}

(a) Department of Commerce data are based in "shipment value" and are reported to reflect manufacturers' wholesale prices.

batch are costly. Simplified glass batch formulations and raw-material costs for a typical container glass* and a low-expansion borosilicate glass (Corning 7070) have been calculated in Tables 16 and 17, respectively. These glass compositions represent two materials which might be used as terrestrial solar-cell encapsulants, the soda-lime-silica because of low price, and the latter for its low expansion. The raw-material cost differs by a factor of 5 , but this difference by itself should not be considered indicative of glass prices, since quality, production volume, and other factors affect pricing. However, the tables show that soda ash and boric acid account for about half the material costs for each of these glasses. Raw-material costs, when combined with lower production volume and melting difficulties, account for borosilicate glasses being priced three to eight times above similar products made from soda-lime-silica glass. Currently, about half the boron compounds produced in the U.S. go into glass and ceramic products, so any dramatic increase in the demand for borosilicate glass could result in a "tight" market for boron compounds (Reference 36).

Of the total energy used by the glass industry, $65-85 \%$ is utilized in melting the glass. When the energy content of the raw materials used in glass making

*The composition of container glass (Table 16) is similar to soda-lime glass used for the tubings and flat shapes. 
Table 16. Simplified Batch Formulation and Raw-Material Costs for Soda-Lime-Silica Container

Glass (Ref. 28)

\begin{tabular}{|c|c|c|c|c|c|c|c|c|c|c|}
\hline \multirow[b]{2}{*}{ Name } & \multirow{2}{*}{$\begin{array}{c}\text { Parts } \\
\text { per } 100 \\
\text { Parts Glass }\end{array}$} & \multirow{2}{*}{$\begin{array}{l}\text { Oxide } \\
\text { Factor }\end{array}$} & \multirow{2}{*}{$\begin{array}{c}\text { Delivered } \\
\text { Cost, } \\
\$ / 1000 \mathrm{~kg}\end{array}$} & \multirow{2}{*}{$\begin{array}{c}\text { Batch } \\
\text { Cost, } \\
\$ / 1000 \\
\text { kg Glass }\end{array}$} & \multicolumn{6}{|c|}{$\begin{array}{c}\text { Composition of Typical Container } \\
\text { Glass, weight percent }\end{array}$} \\
\hline & & & & & $\mathrm{SiO}_{2}$ & $\mathrm{Na}_{2} \mathrm{O}$ & $\mathrm{K}_{2} \mathrm{O}$ & $\mathrm{CaO}$ & $\mathrm{MgO}$ & $\mathrm{Al}_{2} \mathrm{O}_{3}$ \\
\hline Feldspar & 9.35 & $\begin{array}{l}0.066 \\
0.055 \\
0.672 \\
0.193\end{array}$ & 40 & 3.74 & 6.3 & 0.5 & 0.62 & & & 1.80 \\
\hline Soda ash & 22.73 & 0.585 & 80 & 18.18 & & 13.3 & & & & \\
\hline Dolomite & 8.26 & $\begin{array}{l}0.218 \\
0.304\end{array}$ & 15 & 1.24 & & & & 2.5 & 1.8 & \\
\hline Limestone & 12.68 & 0.560 & 20 & 2.54 & & & & 7.1 & & \\
\hline Sand & 66.1 & 1.0 & 14 & 9.25 & 66.1 & & & & & \\
\hline & & & & $\$ 35.11$ & $(72.4)$ & $(13.8)$ & $(0.62)$ & $(9.6)$ & $(1.8)$ & $(1.8)$ \\
\hline
\end{tabular}

(a) Cost data from Reference 35 adjusted to reflect 1976 first quarter prices for ohio area. Note: Numbers in parentheses are nominal values.

Table 17. Simplified Batch Formulation and Raw-Material Costs for Low-Expansion Borosilicate Glass (Ref. 28)

\begin{tabular}{|c|c|c|c|c|c|c|c|c|c|c|c|c|}
\hline \multirow[b]{2}{*}{ Name } & \multirow{2}{*}{$\begin{array}{c}\text { Parts } \\
\text { per } 100 \\
\text { Parts } \text { Glass }\end{array}$} & \multirow{2}{*}{$\begin{array}{l}\text { Oxide } \\
\text { Factor }\end{array}$} & \multirow{2}{*}{$\begin{array}{l}\text { Delivered } \\
\text { Cost, } \\
\$ / 1000 \mathrm{~kg}(\mathrm{a})\end{array}$} & \multirow{2}{*}{$\begin{array}{c}\text { Batch } \\
\text { Cost, } \\
\$ / 1000 \\
\text { kg Glass }\end{array}$} & \multicolumn{8}{|c|}{$\begin{array}{c}\text { Composition of Corning } 7070 \text {, } \\
\text { Weight Percent }\end{array}$} \\
\hline & & & & & $\mathrm{SiO}_{2}$ & $\mathrm{Na}_{2} \mathrm{O}$ & $\mathrm{K}_{2} \mathrm{O}$ & $\mathrm{CaO}$ & $\mathrm{MgO}$ & $\mathrm{Al}_{2} \mathrm{O}_{3}$ & $\mathrm{~B}_{2} \mathrm{O}_{3}$ & $\mathrm{Li}_{2} \mathrm{O}$ \\
\hline Boric acid & 44.44 & 0.563 & 270 & 119.99 & & & & & & & 28.0 & \\
\hline Potash & 0.733 & 0.682 & 340 & 2.49 & & & 0.5 & & & & & \\
\hline Dolomite & 0.329 & $\begin{array}{l}0.218 \\
0.304\end{array}$ & 20 & 0.07 & & & & 0.1 & 0.07 & & & \\
\hline Spodumene & 4.01 & $\begin{array}{l}0.080 \\
0.274 \\
0.646\end{array}$ & $\begin{array}{l}130 \\
---\end{array}$ & 5.21 & 2.59 & & & & & 1.1 & & 0.32 \\
\hline $\begin{array}{l}\text { Lithium } \\
\text { carbonate }\end{array}$ & 2.92 & 0.404 & 2000 & 58.40 & & & & & & & & 1.18 \\
\hline Sand & 67.41 & 1.0 & 14 & 9.44 & 67.41 & & & & & & & \\
\hline & & & & $\$ 195.60$ & $(70.0)$ & $(0.0)$ & $(0.5)$ & $(0.1)$ & $(0.2)$ & $(1.1)$ & $(28.0)$ & $(1.5)$ \\
\hline
\end{tabular}

${ }^{(a)}$ Cost data from Reference 35 adjusted to reflect 1976 first quarter prices for ohio area. Note: Numbers in parentheses are nominal values. 
is considered, the energy consumption increases. Table 18 summarizes the total energy content for flat glass. Energy consumed in other types of glass production are shown for comparison. The data are only for producing primary or raw products, and may not reflect the energy in a finished item. For steel, yield losses associated with secondary forming operations to fabricate wrought products cause the total energy content of the finished products to be about double that of the raw steel; for aluminum the losses are only about 10 percent more. For some glass products, such as glass containers, no secondary forming operations are involved because the containers are final products. However, although the manufacturer uses energy to temper flat glass, it still requires less energy than any other of the materials in Table 18.

In summary, raw material costs, manufacturing costs, volume purchased and other factors influence the price of glass for photovoltaic applications significantly. Soda-lime will probably continue to be more economical than the high transmissivity, low-iron tempered glass or low expansion borosilicate. Average sheet glass at $\$ 1.82 / \mathrm{m}^{2}\left(\$ 0.17 / \mathrm{ft}^{2}\right)$ in 1975 dollars represent rock bottom costs for soda-lime glass. Prices in 1978 dollars, however, were postulated to he in the $\$ 3.23-5.38 / \mathrm{m}^{2}\left(\$ 0.30-0.50 / \mathrm{ft}^{2}\right)$ for this same type of glass when purchased in large quantities $21-10$ million $\mathrm{ft}^{2}$. Estimates of glass prices in terms of 19751980 dollars are summarized in Table 19.

Table 18. Total Energy Consumed in Manufacturing Various Types of Materials (Ref. 28)

\begin{tabular}{|c|c|c|c|}
\hline \multirow[b]{3}{*}{ Material } & \multirow{3}{*}{$\begin{array}{c}\text { Approximatc } \\
\text { Density, } \\
10^{-3} \mathrm{~kg} / \mathrm{m}^{3} \\
\left(1 \mathrm{~b} / \mathrm{ft}^{3}\right)\end{array}$} & \multicolumn{2}{|c|}{$\begin{array}{c}\text { Energy Content (1970) Per Unit } \\
\text { of Product }\end{array}$} \\
\hline & & Weight & Volume \\
\hline & & $\begin{array}{c}10^{6} \mathrm{~J} / \mathrm{kg} \\
\left(10^{6} \mathrm{Btu} / \text { ton }\right)\end{array}$ & $\begin{array}{c}10^{6} \mathrm{~J} / \mathrm{m}^{3} \\
\left(10^{6} \mathrm{Btu} / \mathrm{ft}^{3}\right)\end{array}$ \\
\hline $\begin{array}{l}\text { Glass } \\
\text { containers }\end{array}$ & $2.50(156)$ & $21.1(18.2)$ & $52.8(1.42)$ \\
\hline $\begin{array}{l}\text { Primary } \\
\text { aluminum }\end{array}$ & $2.72(170)$ & $203.9(175.8)$ & $554.6(14.9)$ \\
\hline Raw steel & $7.84(489)$ & $22.4(19.3)$ & $175.6(4.72)$ \\
\hline $\begin{array}{l}\text { Polyvinyl } \\
\text { chloride } \\
\text { resin }\end{array}$ & $1.40(87.4)$ & $96.3(8.3 .0)$ & $134.8(3.63)$ \\
\hline $\begin{array}{l}\text { Polystyrene } \\
\text { resin }\end{array}$ & $1.06(66.1)$ & $134.2(115.7)$ & $142.3(3.82)$ \\
\hline
\end{tabular}


Table 19. Estimates of Prices of Photovoltaic Glass for Large Quantities

Thickness: 3.175 (0.125 inches)

- Large Volume Purchase

\begin{tabular}{|c|c|c|c|}
\hline \multirow[b]{2}{*}{ Type of Glass } & \multicolumn{3}{|c|}{ Price $\$ / m^{2}\left(\$ / f t^{2}\right)$} \\
\hline & 1975 & 1978 & 1980 (Est.) \\
\hline Soda-lime & $\begin{array}{c}1.83 \\
(0.17) *\end{array}$ & $\begin{array}{c}3.34-5.38 \\
(0.31-0.50)\end{array}$ & $\begin{array}{l}3.87-6.24 \\
(0.36-0.58)\end{array}$ \\
\hline Low-iron Tempered & --- & $\begin{array}{l}7.50 \\
(0.70)\end{array}$ & $\begin{array}{l}8.70 \\
(0.812)\end{array}$ \\
\hline Borosilicate & --- & $\begin{array}{l}5-15 \\
(0.46-1.39)\end{array}$ & $\begin{array}{l}5.8-17.4 \\
(0.53-1.61)\end{array}$ \\
\hline
\end{tabular}

*Price from Table 11.

Note: Price increase of $8 \%$ assumed per year. 
SECTION II.

GLASS PROCESSING

\section{A. GLASS IMPROVEMENTS} made :

Three major areas exist where improvements in photovoltaic glass can be

(1) Reduction of iron content

(2) Tempering

(3) Anti-reflection coatings

\section{Improvement of Bulk Effects}

As stated previously, improvement of the solar transmission characteristics of glass is possible by reduction of the ferrous oxide (FeO) component which gives a greenish tinge. See Figure 1.

\section{Tempering}

Two general methods are available for strengthening glass (a) tempering in air and (b) tempering by chemical diffusion. In both methods, advantage is taken of the fact that brittle materials such as glass tend to fracture in tension at a surface. Glass virtually never breaks in compression or internally. Therefore, in a sheet of glass that is subjected to bending, it is desirable to have the residual compression in the surface area. This is accomplished by quenching (usually by an airflow) the surfaces while the glass is in a plastic state. The surfaces of the glass are at lower temperatures as a result of the quench, but there is no residual stress immediately after the quench because the core is plastic. However, on cooling thereafter, the core will attempt to contract a greater amount than the surface because it falls through a greater temperature interval. On reaching room temperature, there is a tension in the core and a compression in the surface. This can increase the strength of the glass to twice that of ordinary annealed glass. Upon breakage, the stored energy will be released so that the glass breaks into many small pieces. Consequently, glass cannot be cut after tempering. Thermal tempering of soda lime glass is practical only for thicknesses greater than $3 \mathrm{~mm}$ ( $1 / 8$ inch). Thermally strengthened glass $i$ is glass that is strengthened to a lower degree than is tempered glass.

Glass can be tempered by a chemical method to a strength 10 times that of ordinary glass. In this method, the surface of glass containing sodium is exposed to a solution of potassium ions. Chemical exchange takes place and the "wedging in" of the larger potassium ions causes surface compression. This occurs 
over the outermost 4 microns of the glass surface. This process can be used to strengthen complex shapes or sheets as thin as $1 \mathrm{~mm}(0.040 \mathrm{in.})$. The outer surface of aircraft laminated windshields consits of chemically strengthened glass bent elastically to conform to the curved-windshield geometry during an autoclave lamination process. (References 37-38). Thicker pieces of glass would not permit cold bending to the desired aerodynamic configuration and would require preforming, followed by strenthening, to form a curved part. Although the technique is normally used for premium quality glass products, a salt-spray treatment followed by chemical strengthening in the annealing lehr is being developed as a high-speed process for making lighter weight glass containers (Reference 39) and may eventually be applicable to photovoltaic glass.

Laminated safety glass is either annealed, tempered, or chemically strengthened glass which is laminated either to arditinnal glass shepts or to organic polymers (Reference 40). Polyvinyl butyral film is the most commonly used adhesive layer. Automotive and some aircraft windshields consist of two pieces of tempered glass laminated with polyvinyl butyral. Boeing 747 and Lockheed L-1011 aircraft windshields have high-impact-resistance organic polymers as the inner sheets and chemically strengthened glass as an abrasion-resistant outer sheet (Reference 41).

\section{Anti-Reflective Coatings}

For many years, coatings have been applied to optical components to control the reflectivity of light, both across a broad spectrum and in selected wavelength ranges. In addition, methods exist for chemically treating surfaces to reduce light reflection. Aspects of this "surface technology" were reviewed in this study because coating and/or surface treatments can affect (1) the efficiency of the glass transmission (2) the selection, processability. and/or compatibility of encapsulation materials, and (3) the cost of the glass. The discussion below treats briefly selected information on the following topics:

(a) Reflection losses from uncoated surfaces

(b) Single-layer antireflection coatings

(c) Low-reflectivity glass surfaces

a. Reflecilon Losses from Uncoated Surfaces. Light impinging on a material is either reflected, transmitted, or absorbed, depending on the optical properties of the material and the adjacent media. In the simple case of a lowabsorption material such as glass, most of the light is transmitted or reflected. The reflection losses at each surface are related to the difference in index of reflection between the environment $\left(n_{1}\right)$ and the material $\left(n_{2}\right)$ by the Fresnel equaliull (References 42-43).

$$
R=\left(\frac{n_{1}-n_{2}}{n_{1}+n_{2}}\right)^{2}
$$


For window glass $\left(\mathrm{n}_{1}=1.52\right)$ and air $\left(\mathrm{n}_{2}=1.0\right)$, the reflection loss from the front surface of the glass is 4.3 percent. If the glass does not absorb any of the 9.57 percent of the transmitted light, and the back boundary is air, 4.1 percent $(0.957 \times 4.3)$ is reflected from the back surface of the glass resulting in a total transmission of 91.6 percent. This total value is typical for common soda-lime-silica glasses, and is not significantly affected by thickness, unless the absorption is high (as with tinted or colored glasses).

The reflection loss at the back surface of the glass may be reduced by employing a pottant between the glass and the solar cells. Since organic pottants commonly have refractive indises between 1.4 and 1.5 , reflection losses are reduced $2.8 \%$ to $4 \%$ respectively.

b. Single-Layer Antireflection Coatings. Because solar-cell efficiency depends on the amount of light actually absorbed by the cell as well as the conversion efficiency, it is desirable to reduce reflection losses which occur at both the front and back surfaces of the cover material. In the preceding discussion of reflection losses from bulk (uncoated) materials, it was shown that a coating material with an index intermediate between that of air and the glass is effective in reducing reflection loss from the glass surface. If the coating material is applied as a coating $(1 / 4 \lambda)$ such that the light is "in phase" as it passes through the coating, still lower reflection losses can be obtained. For quarter-wavelength optical coatings, reflection losses (R) for a particular wavelength are given by the equation:

$$
\mathrm{R}=\left(\frac{\mathrm{n}_{1}^{2}-\mathrm{n}_{\mathrm{o}} \mathrm{n}_{2}}{\mathrm{n}_{1}^{2}+\mathrm{n}_{\mathrm{o}} \mathrm{n}_{2}}\right)^{2}
$$

where $\mathrm{n}_{0}=$ index of the environment, $\mathrm{n}_{1}=$ index of the coating material, and $\mathrm{n}_{2}=$ index of the bulk material (References 42-45). However, the thickness of the optical coating is critical tor meeting the "in-phase" criterion, which occurs when the otpical thickness,

$$
\left.\mathrm{n}_{1} t_{1}=\frac{\lambda}{4}, \frac{3 \lambda}{4} \text {, etc. (Reference } 42\right)
$$

Because the indices of materials vary with wavelength, the in-phase coupling occurs at a specific wavelength and interference occurs at adjacent wavelengths. This results in a reflection minimum at the design wavelength, above and below wiich reflection losses increase (Keference 46).

On examination of the equation above, it can be observed that reflection losses will be essentially zero when $n_{1}^{2}=n_{0} n_{2}$, or when the coating has an index $n_{1}=\sqrt{n_{0} n_{2}}$. For an air-glass interface, a coating material with index $\mathrm{n}_{1}=\sqrt{1 \times 4.0}=2.0$ would give optimum antireflection characteristics if deposlited Lil Llie pruper uplical thickness according to the equation above. 
$\mathrm{MgF}_{2}(\mathrm{n}=1.39)$ has the lowest index of those inorganic materials which are reasonably stable in the environment, adhere well to glass, and are reasonably abrasion resistant. It reduces the single-surface reflection loss to about 1.26 percent, or one-quarter that of uncoated glass. Its use has become common on space solar-cell covers, as well as aircraft-instrument covers, camera lenses, and other glass-covered optical components used in protected environments (References 47-49).

c. Low-Reflectivity Glass Surfaces. In this section, methods of producing weather-resistant, low-reflectivity glass surfaces by chemical etching, ion bombardment, and the application of organic coatings are discussed because the technology is especially relevant to terrestrial solar-cell encapsulation systems. The use of these methods on low-iron glass should produce efficient photovoltaic șystems.

Chemical etching of soda-lime glass in $\mathrm{HF}$ baths to reduce surface specular. reflections has been used by the glass industry for some time, and this method has been pursued actively by Motorola under LSA contract for IPL. By the proper control of treatment conditions, an etched layer with an effective quarterwavelength thickness can be obtained. The layer actually reduced reflection losses rather than changing the reflection from specular to diffuse. Nicoll (Reference 50) produced such films on window glass by exposing samples above HF solutions ( $1-5$ percent) at room temperature. True interference films were formed only with glasses containing substantial $\mathrm{CaO}$, leading him to speculate that the process formed $\mathrm{CaF}_{2}$ films rather than a porous skeleton film. Thomsen, also at RCA (Reference 51), produccd low-reflection films on glass by immersing the material in warm fluosilicic acid $\left(\mathrm{H}_{2} \mathrm{SiF}_{6}\right)$. Recently, one US company has revived the latter process for treating the surfaces of thermal collector covers made of window glass (Reference 52).

If two-layer "coatings," produced by treatment in two baths of different potency, are used, the sharp minimum in the reflection curves can be changed to a broad band characterized by double minimums, one on each side of the 500-nm peak in the solar spectrum. Reflectance from one sample was less than 1 percent from. 350 to $800 \mathrm{~nm}$, with a broad minimum in the visible range (Reference 53).

It has been found that exposure of glass to fluoroboric acid vapor produced better results than use of HV vapor or hydrofluorosilicic acid-bath processes (References 54 and 55).

Polymeric coatings with low indices of refraction also offer potential for reducing the reflectivity of glass surfaces. NASA-Ames investigators have used plasma polymerization to deposit fluorocarbon films on moisture-sensitive alkali-halide windows while Bell Laboratories has used a plasma-polymerization process to deposit silica coatings from organosilanes (References. 56-58). USSR researchers have combined fluoropolymer and lead germanate for making durable AR coatings (Reference 59).

Ion Bombardement is another technique which can be used to lower the reflectivity of glass surfaces (Reference 60). Data for untreated and kryptontreated glass shows that transmission in the visible range is increased by 1.95.8 percent by the treatment (References 61-62). 


\section{B. BONDING TO GLASS SURFACES}

If we are to bond wood, metal or other surfaces to glass, a primary criterion for adhesion of these materials is needed. The primary problem is that an ordinary glass surface contains microfissures that permit water vapor to penetrate beneath the adherent material and to promote delamination. Consequently, for many applications, a primer system is required to seal the microfissures against water penetration.

There are many materials that adhere satisfactorily to glass. Silicone primers can be used as an adherent surface and they are available from a number of sources, such as Dow Chemical. Selection of the exact primer varies with the type of coating or adhesive system being used (References 63-65). The effectiveness of a given primer varies with the type of product being used even though they are of the same polymer type. Factors such as fillers, curing agents and degree of cure can have an effect on the strength of the adhesion.

JPL has completed a recent contract that treats the general theory of bonding agents. For further details, see Reference 66. 


\title{
SECTION III
}

\author{
GLASS AGING
}

Upon exposure to the natural solar environment, glass undergoes degradation to a greater or lesser extent depending on a number of factors. Primary among these is the natural humidity in the air which attacks glass. Other factors include chemical composition, temperature cycling and attack by atmospheric pollutants.

Although glass is a very good barrier in protecting the solar cells from the external environment, it is not perfect. Certain gasses, such as helium, can diffuse through it although at a low rate.

Most glasses do not turn color upon exposure to the ultraviolet component in sunlight. However, some glasses will turn colors dependent upon the chemical composition. A recent study of glass aging has been completed by Battelle (Reference 25) and Sandia (to be published). Experiments thus far have indicated that the aluminosilicate glasses are the most resistant to accelerated aging test environments. The borosilicates are next with soda-lime glass being more susceptible to environmental weathering. Dust contaminants are probably a factor, either through chemical reactions with the glass surface or accelerated aging due to effects of cleaning solvents. The reader is referred to these reports for further details as well as the following (References 23 and 67). A summary of recent general observations on glass are given in Table 20.

Dimensional stability with time is very important.in many applications including long-lived photovoltaic arrays. If the glass is not carefully annealed and aged, it may undergo a slight contraction with time. This effect presumably causes changes in some glass properties, such as density, index of refraction and strength.

In summary, the aging response of glass encapsulation is found to vary strongly with the local environment and this should be considered in long-lived photovoltaic ençapsulation systems.

Table 20. Summary of Recent Observations on Glass Weathering

1. The data on weathering of glasses are inconsistent. The error limits encountered in corrosion studies are quite large.

2. Aluminosilicate glasses are usually more durable than sodalime-silicate glasses such as low-iron float glass.

3. Glasses are usually more durable in acid environments than in alkali environments.

4. Glass corrosion in high $\mathrm{pH}$ environments, above 12 , is due to the dissolution of the entire glass network. This process shows a linear time dependence. 
Table 20. Summary of Recent Observations on Glass Weathering (Continuation 1 )

5. Environments which tend to remove leach products from the glass surface usually lead to less corrosion than those which cause buildup of these products on the surface.

6. Corrosion of common glasses in water is usually due to an exchange between alkali ions from the glass and protons from the water. This process is diffusion-controlled and exhibits a square root time-dependence.

7. Large quantitics of water are less corrosive than are thiil films of water.

8. Glasses under stress due to bending, etc., will usually undergo faster corrosion rates than otherwise.

9. Glass usually lasts longer in low-humidity than in high-humidily environments.

10. Most glasses can usually be pitted by particles of all sizes, such as sand.

11. Small particles trapped in the cracks in the glass surface are the most difficult to remove.

12. Weathering of glass surfaces is usually related to the type of clleaning agent used. 
SECTION IV

GLASS PERFORMANCE

\section{A. GENERAL}

The ability of glass to function successfully in the terrestrial solar environment for long periods of time is dependent upon the design parameters. Important parameters include the following:

(1) Spectral characteristics

(2) Hail resistance

(3) Wind resistance

(4) Abrasion effects

\section{B. SPECTRAL CHARACTERISTICS}

1. Transmissivity

A primary characteristic of glass for photovoltaic applications is the transmissivity. The light is reflected and/or transmitted through the surface as specular (direct) and diffuse (scattered) components. Of course, the purpose of a good design configuration is to maximize both the specular and the diffuse components that penetrate the glass and impinge on the solar cell. Iron content is a main contributor to reduction in transmission of sunlight. Figure 14 shows the reduction of solar cell output for various percentages of iron in glass. See Reference 33.

Silicon solar cells utilize the sunlight in the frequency range of approximately $400-1.1 \mathrm{~nm}$. The index of refraction of soda-lime glass varies slowly over this region. Figure 15. It is important that the glass chosen for solar cell encapsulation have high transmissivity in this range. Data on solar transmission in glass of various thicknesses and compositions are shown in Tablc 21.

The spectral transmissivity of soda lime glass is shown in Figure 16 compared to other types of glasses, while Figure 17 shows a spectral distribution for $6.35 \mathrm{~mm}$ ( $0.25 \mathrm{in.)}$ thick clear float glass. The transmission versus wavelength for a special low-iron Schott glass (Solawite ${ }^{\mathrm{R}}$ ) is shown in Figure 18. along with the percent solar radiation in 4 separate frequency ranges as given by Srhott.

Because of its low coefficient of expansion, borosilicate glasses may prove useful in special encapsulation systems in which the glass is integrally bonded to the silicon cells. See Reference 28. Experiments have indicated that this is possible except for either very thin glass or solar cell dimensions. 


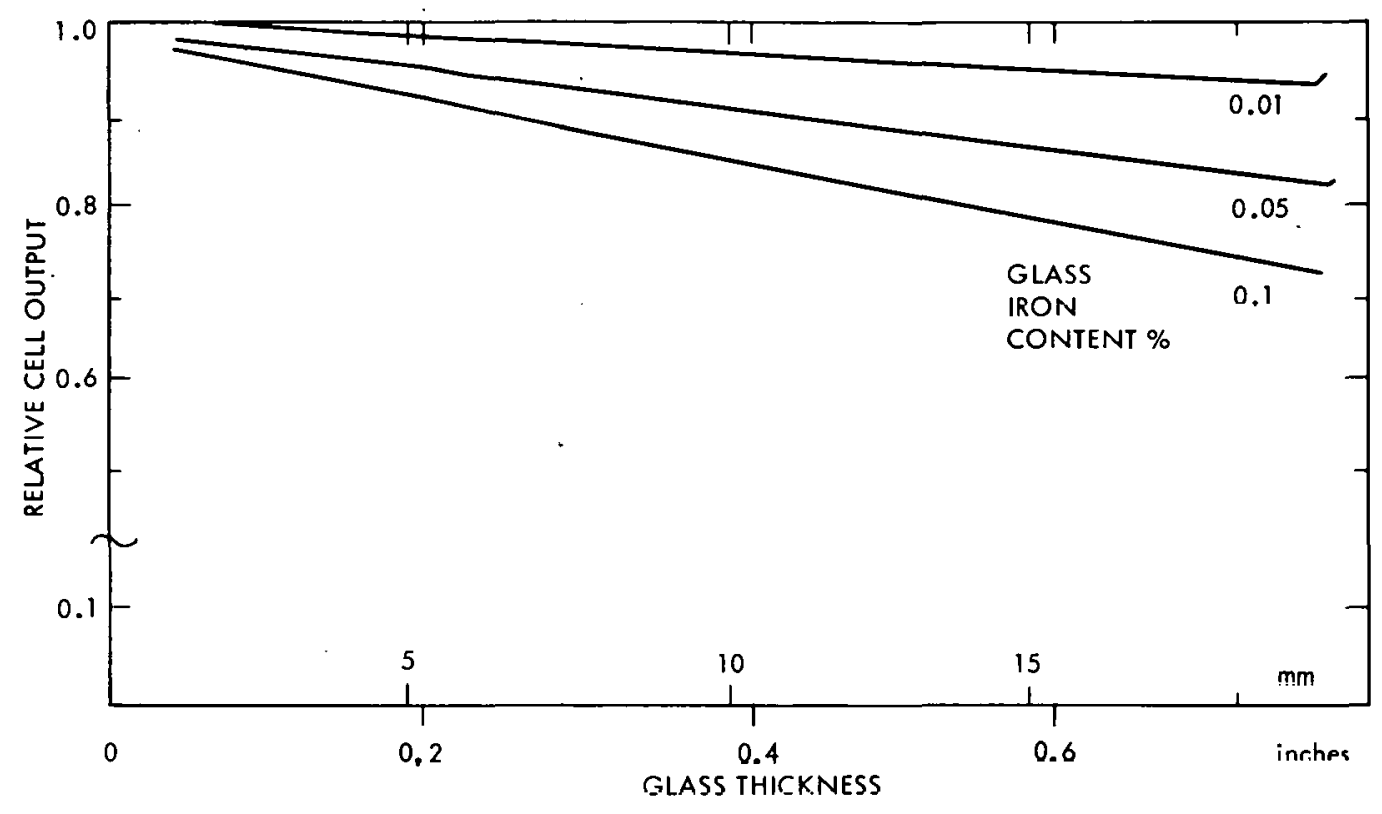

Figure 14. Kelative léli Uutput Versus

Glass Thickness (Ref. 33)

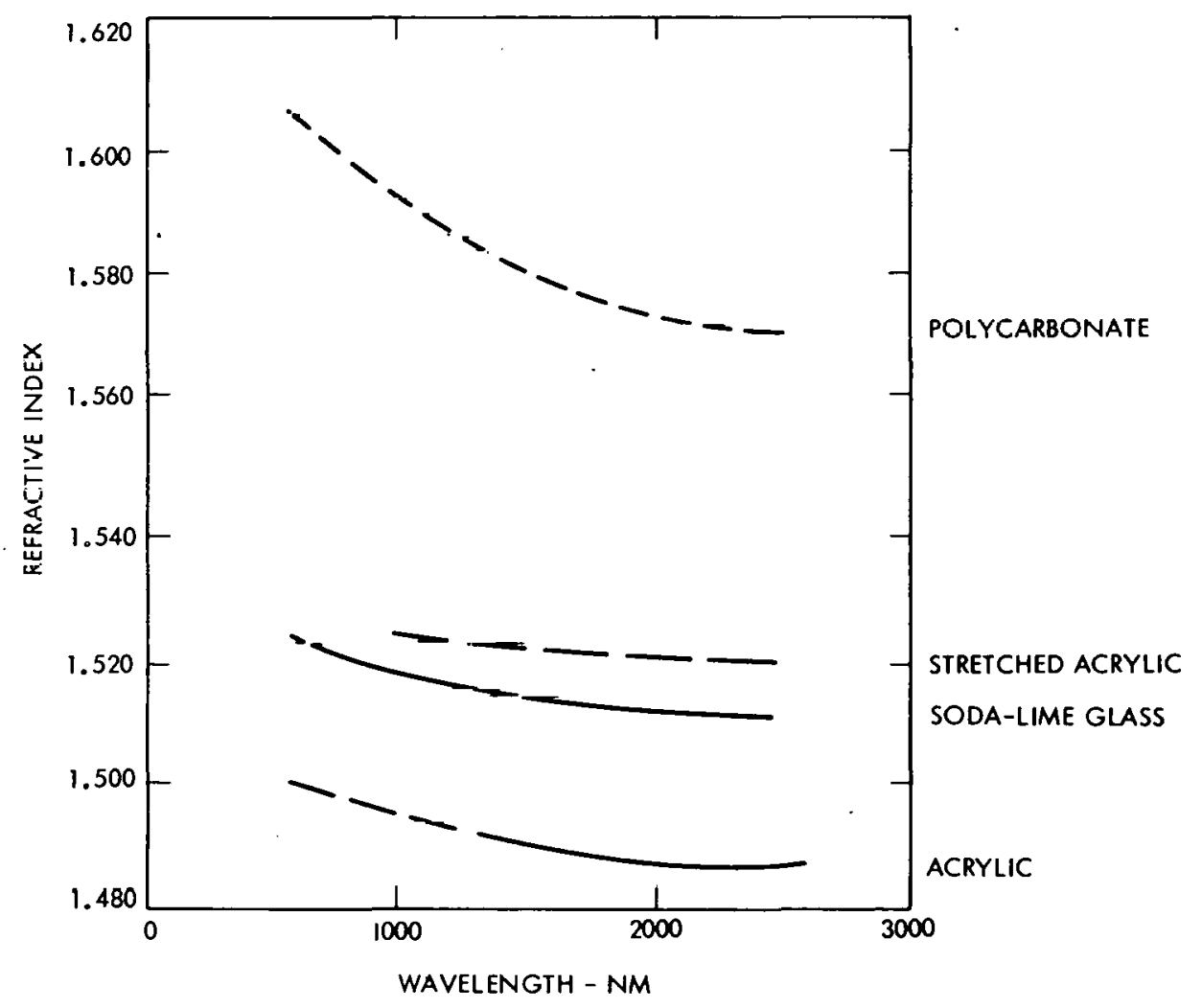

Figure 15. Refractive Index Versus Wavelength for Several Transparent Materials (Ref. 28) 
Table 21. Solar Transmittance Properties of Manufactured Glass (Adapted from Reference 25)

\begin{tabular}{|c|c|c|c|c|c|c|}
\hline \multirow[b]{2}{*}{ Manufacturer } & \multirow[b]{2}{*}{ Process } & \multirow[b]{2}{*}{ Composition } & \multicolumn{2}{|c|}{ Thickness } & \multicolumn{2}{|c|}{ Solar Transmittance } \\
\hline & & & Tested & Possible & Measured & Possible \\
\hline 4 & $\begin{array}{l}\text { Lo-Iron } \\
\text { Float }\end{array}$ & Soda Lime & 0.125 & & 0.847 & \\
\hline 2 & Float & Soda Lime & 0.125 & & 0.838 & \\
\hline 7 & Fusion & $\begin{array}{l}\text { Alumino- } \\
\text { silicate }\end{array}$ & 0.110 & $>0.020$ & 0.903 & \\
\hline 8 & Fusion & $\begin{array}{l}\text { Alumino- } \\
\text { silicate }\end{array}$ & 0.090 & : & 0.910 & \\
\hline 9 & Fusion & $\begin{array}{l}\text { Alumino- } \\
\text { silicate }\end{array}$ & 0.060 & & 0.909 & \\
\hline 14 & Fusion & $\begin{array}{l}\text { Lime } \\
\text { Borosilicate }\end{array}$ & 0.045 & & $0.876^{\mathrm{a}}$ & $>0.91$ \\
\hline 10 & Rolíed & Soda Lime & 0.125 & & 0.891 & \\
\hline 3 & Float & Soda Lime & 0.125 & $>0.105$ & 0.844 & $>0.88$ \\
\hline 15 & Float & Soda Lime & & $>0.085$ & & $>0.88$ \\
\hline 1 & Float & Soda Lime & 0.125 & & 0.831 & \\
\hline 5 & $\begin{array}{l}\text { Mid-Trnn } \\
\text { Float }\end{array}$ & Soda Lime & 0.125 & & 0.866 & \\
\hline 6 & $\begin{array}{l}\text { Lo-Iron } \\
\text { Float }\end{array}$ & Soda Lime & 0.125 & $>0.060$ & 0.881 & $>0.89$ \\
\hline 11 & $\begin{array}{l}\text { B270 Sheet } \\
\text { Rolled }\end{array}$ & Soda Lime & 0.120 & & 0.913 & \\
\hline
\end{tabular}

${ }^{a}$ Normal hemispherical transmittance of split and flattened tubing. 

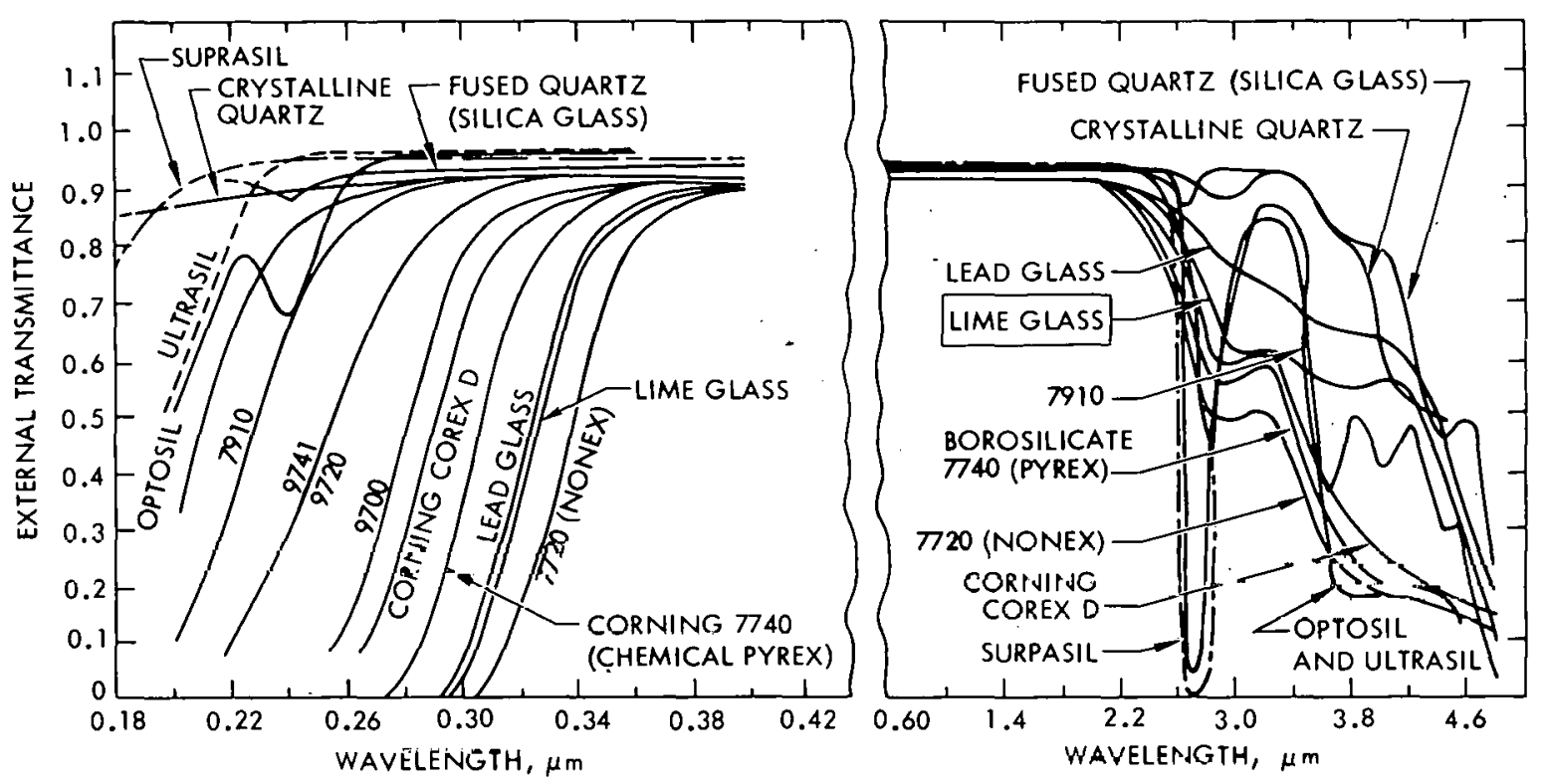

Figure 16. The External Transmittance of Several Samples of Corning and Amersil Glasses. (Ref. 8)

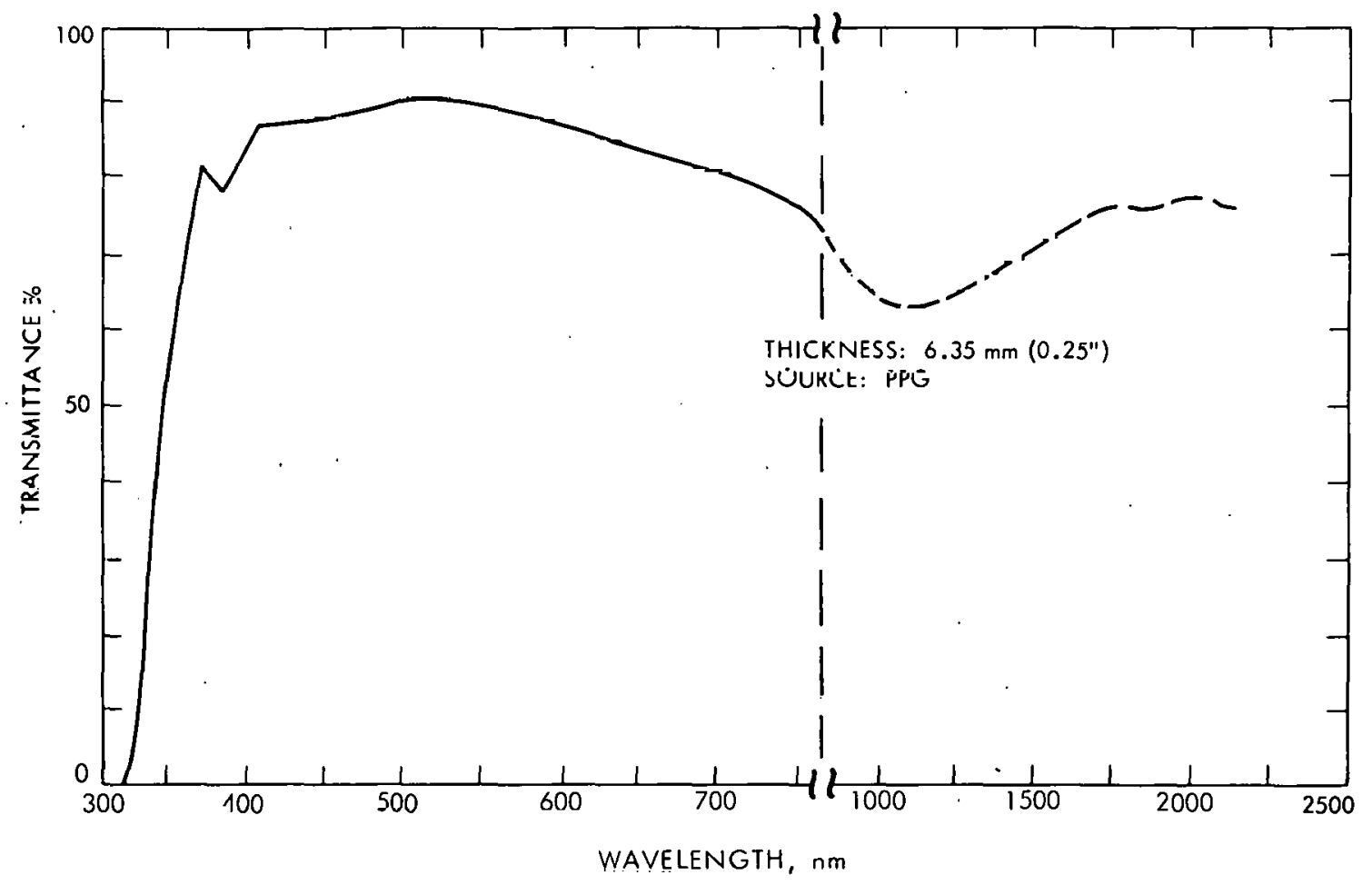

Figure 17. Spectral Transmittance Versus Wavelength for. $1 / 4$ Inch Clear Float Glass 


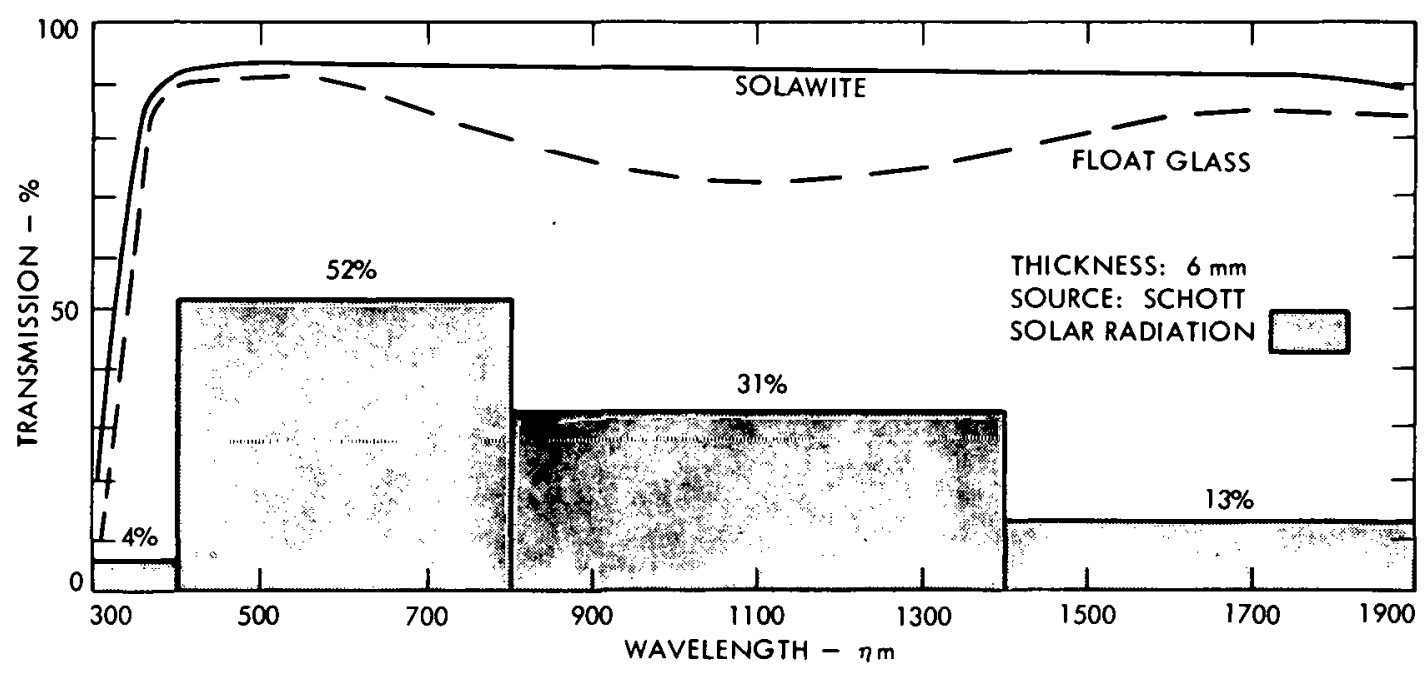

Figure 18. Transmission Versus Wavelength for Schott Low-Iron Silicate SolawiteR

\section{Performance Degradation from Dust}

JPL test results show that recent environmental particles on glass can reduce the light transmission and hence electrical output of the solar cells if uncleaned. The exact amount varies with a number of environmental factors, such as altitude, geographical location, etc. See Figure 19. Rain and/or snow can sometimes clean the glass appreriably.

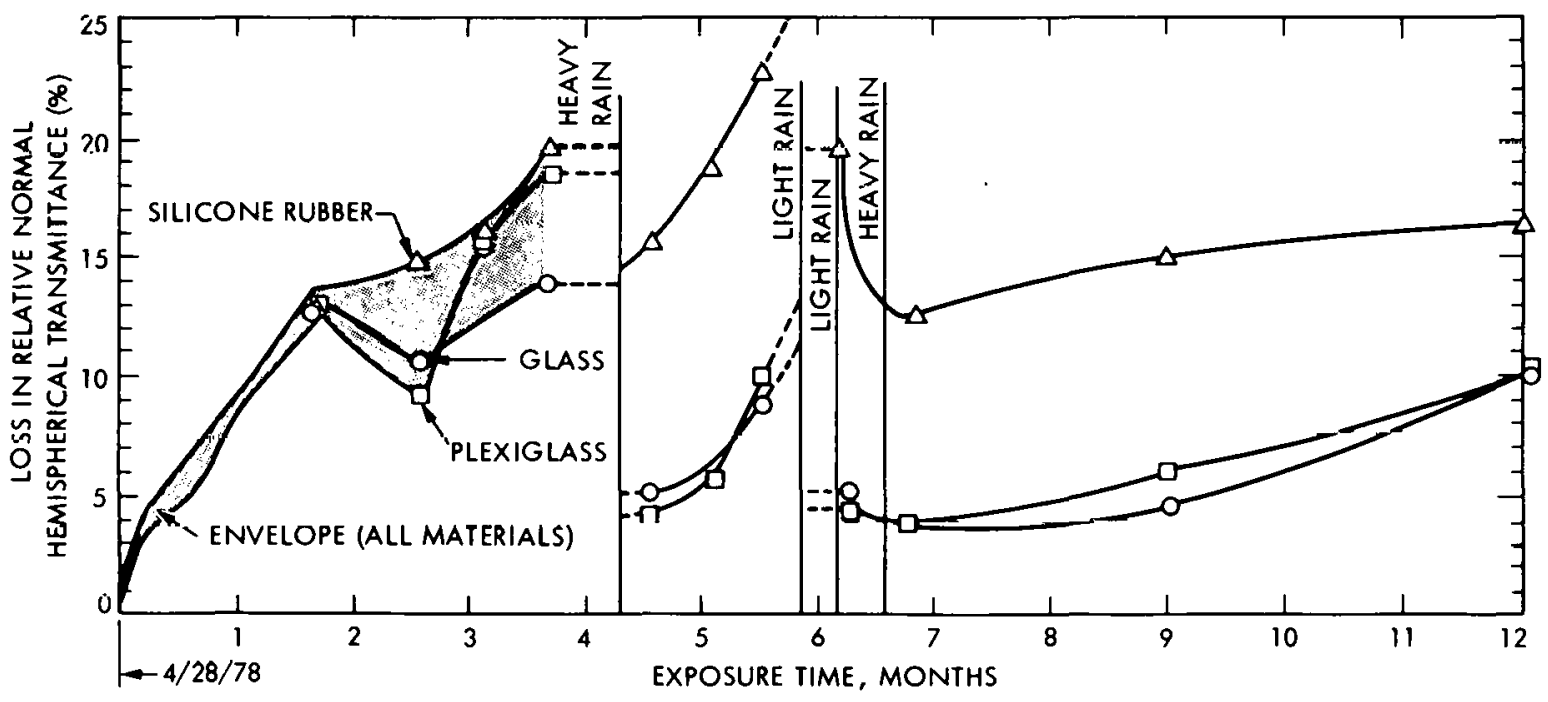

Figure 19. Relative Transmittance of Materials After Exposure at AQMD Site (Outdoor Material Exposure) 
The effects of dirt on the solar module electrical output as measured by the decrease in short circuit current are shown in Figure 20 for the Los Angeles locale. See Reference 68. In general, electrical power degradation of 3-6\% per month can be expected without cleaning near industrial areas.

A number of effective cleaning materials are currently available for glass. The techniques of washing using high pressure (500-1000 psi) water with a sheeting agent is reported to be very good in comparison to other methods. Cleaning materials and techniques are beyond the scope of this report. (See References 25 and 67.)

\section{HAIL RESISTANCE}

JPL has performed studies directed toward assessment of the risk of hail to photovoltaic systems. See References 67 and 70 . Fortunately, not all photovoltaic arrays must be designed for hail impact because it is a regional phenomenon in the US, occurring primarily in the Midwest. Northern Colorado and Southern Wyoming are noted for their frequent storms of this type. Recently, Sandia Corp. has published a report on an intense New Mexico storm composed of high speed $(>50 \mathrm{~km} / \mathrm{hr}$ ) hailstones greater than $6.35 \mathrm{~mm}(0.25 \mathrm{in.})$ in diameter (Reference 71$)$. For one glass concentrator, $5 \%$ of the exposed glass was damaged. Only glass thinner than $254 \mathrm{~mm}$ ( 0.1 in.) was damaged.

JPL hail test results are summarized in Figure 21 . The shaded areas indicate the regions where glass breakage may occur.

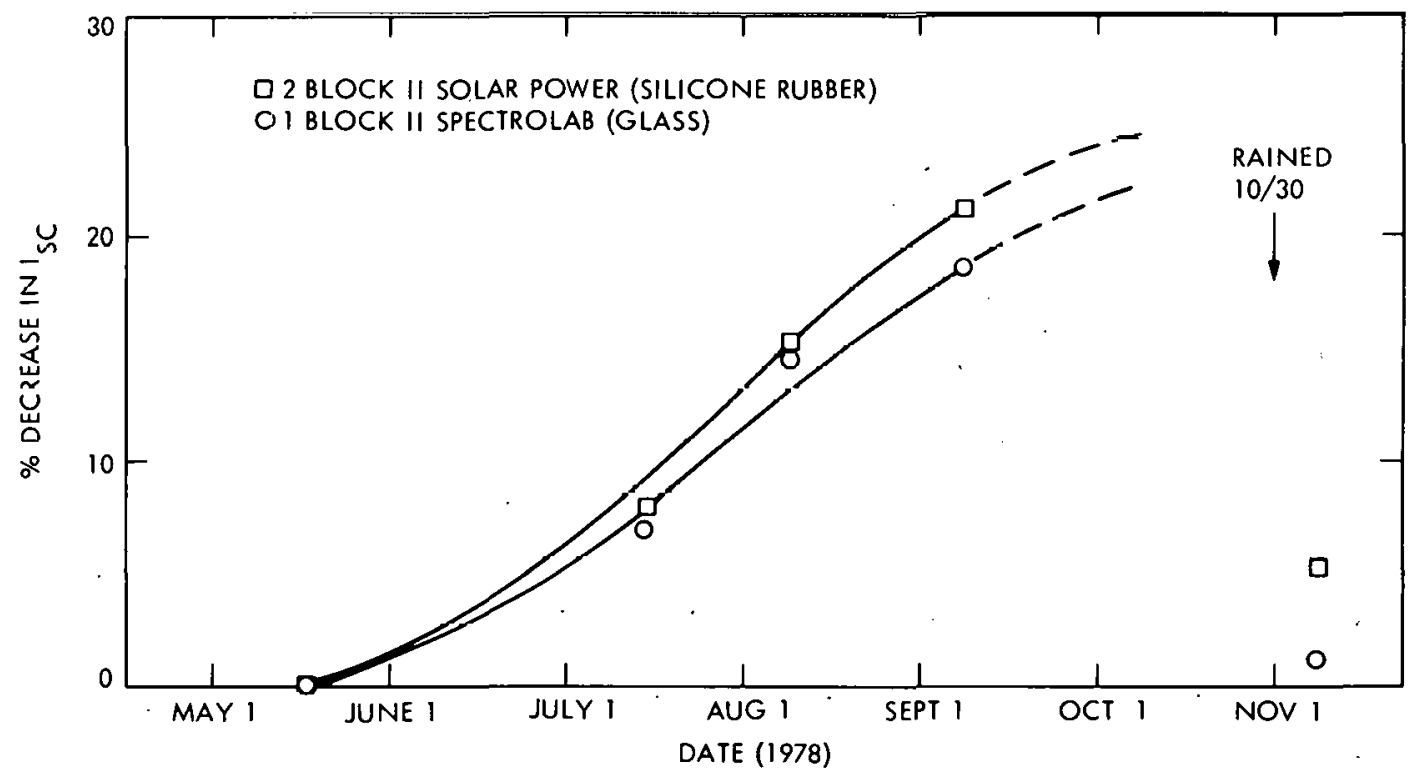

Figure 20. Cumulative Effects of Dirt

(Modules Not Washed) 
TOP SURFACE

OF PANEL

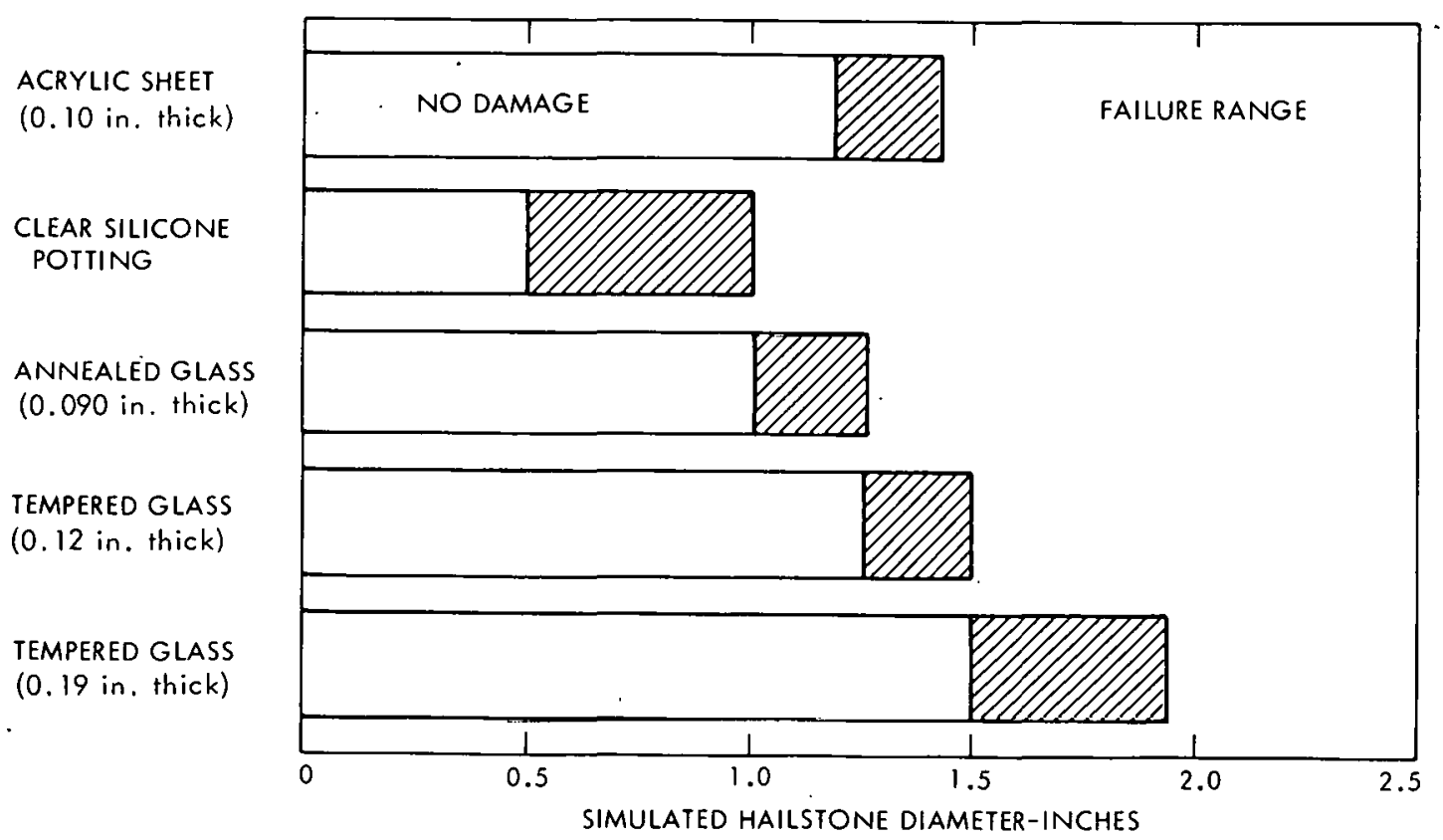

Figure 21. Type of Photovoltaic Panel Material Versus Simulated Hailstone Diameter (Ref. 70)

\section{WIND RESISTANCE}

An important design parameter for windy sites is the velocity distributions for various photovoltaic module geometries. Considerable analyses have been complated by the Boeing Company under contract with JPL (Reference 72). Once the wind loading is determined, the wind resistance of the various types of glasses can be obtained from conventional architectural sources and the glass conpanies. Wind load performance data is currently available, for example, from PPG Industries (Reference 73).

Strength is an important property of glass used for photovoltaic applications. Glass strength varies with the conditions of the test and, in general, the results are less than the theoretical strength. At present, it is believed that glass strength depends upon the condition of the surface. Usually strong glass has fewer flaws and scratches. For small test specimens, such as fibers, it appears that they may be stronger than the bulk pieces partly because of this effect as well as others. See Reference 74.

The structural behavior of glass is such that breakage risk must be determined by using statistical theory. Failure always results when a tensile component of stress exceeds the tensile strength of the plate at a particular location. Stress is influenced by plate geometry, support conditions, surface qualicy, type and rate of loading and other factors. 
The probability of breakage for float glass has been calculated for large plates using the finite-element by C. R. Tsai. See Reference 75. The data on probability of glass breakage for short duration loads from PPG (Reference 76) coupled with methods for extending the data to longer loads permits the designer to determine specific thickness requirements. D. M. Moore of JPL has evolved the latter methods (Reference 70). The glass strength versus probability of failure for one minute duration over one square meter is shown in Figure 22.

The results are shown for new sheet and float glass, new plate glass, and weathered glass.

In addition to the strength of the glass encapsulation, the abrasion due to environmental effects may be important. These are treated in the following SECLIUL.

\section{E. ABRASION EFFECTS}

Abrasion tests on $6.35 \mathrm{~mm}$ ( $1 / 4 \mathrm{in.)}$ thlck soda-lime glass have been performed by Taketani and Arden using particles ranging from 3.75 to 22.5 grams.

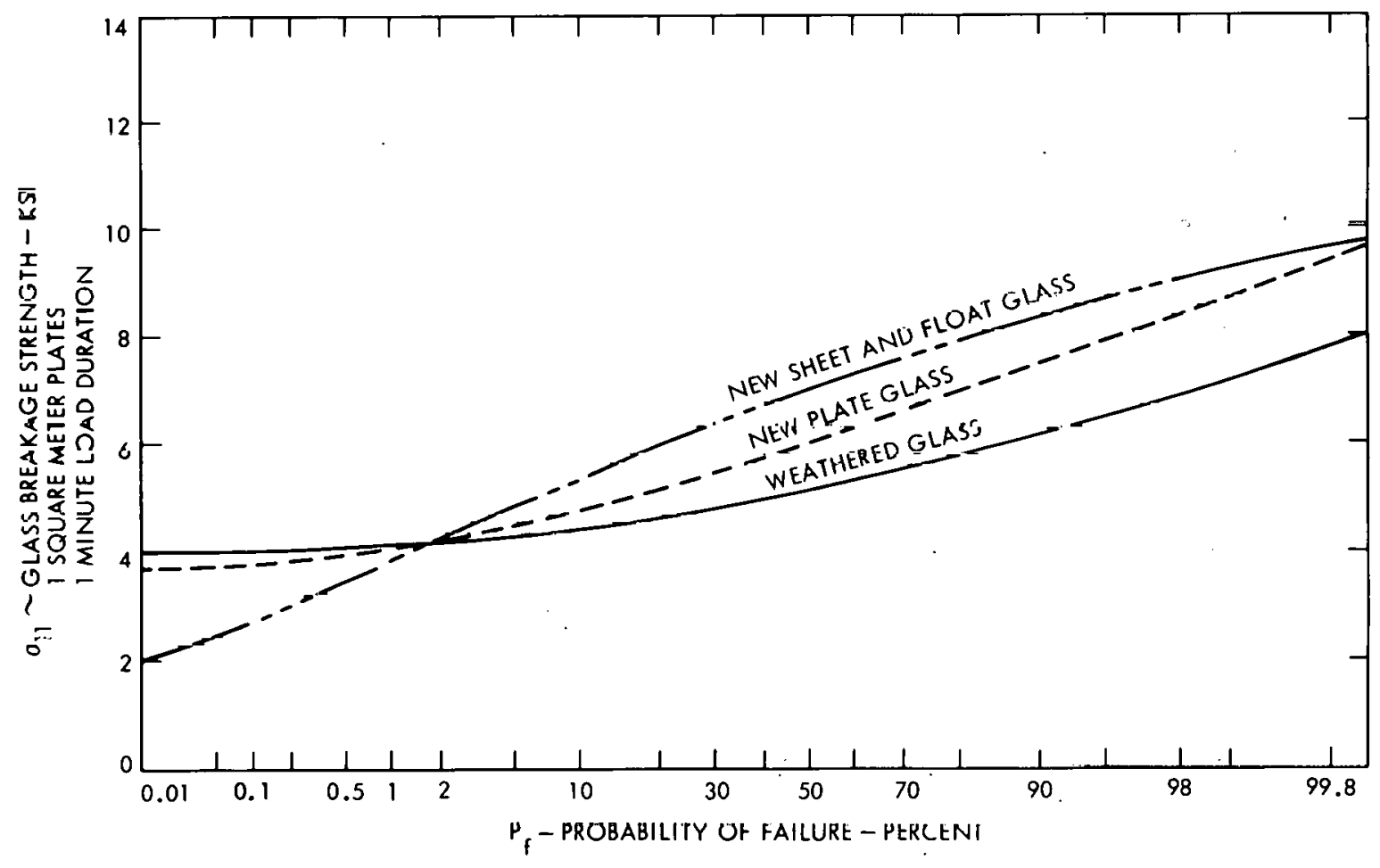

Figure 22. Recommended Design Values for Breakage Strength Versus Probability of Failure for 1 Square Meter, SimplySupported, Annealed Glass Plates Subjected to a Uniform Normal Pressure Load of 1 Minute Duration 
See References 23, 26 and 77. The purpose was to determine relative loss of transmission with abrasive dose, impact velocity and particle size. Velocities between 12-18 meters per second were used. This particular simulation was for the desert environment in the Southwestern United States. Ihe abrasive material, silica flour 105-125 micrometers in diameter, was blown onto the surface at normal incidence.

Figure 23 shows the results of these experiments. A functional relationship exists between the total kinetic energy of the incident particles and the soda-lime glass transmission 1oss. From this information, and loss in transmission for $6.35 \mathrm{~mm}$ ( 0.25 inch) thick glass in abrasive environments can be estimated. These data indicated that glass was superior to the acrylics tested. For further details, see Reference 77 .

Further work on abrasive effects on other types of glass, such as borosilicates, remains to be undertaken. Weathering tests, Reference 78, show that the aluminosilicates and borosilicates are more durable than soda-lime to humidity effects, and the implication is that the same would be true of abrasion tests.

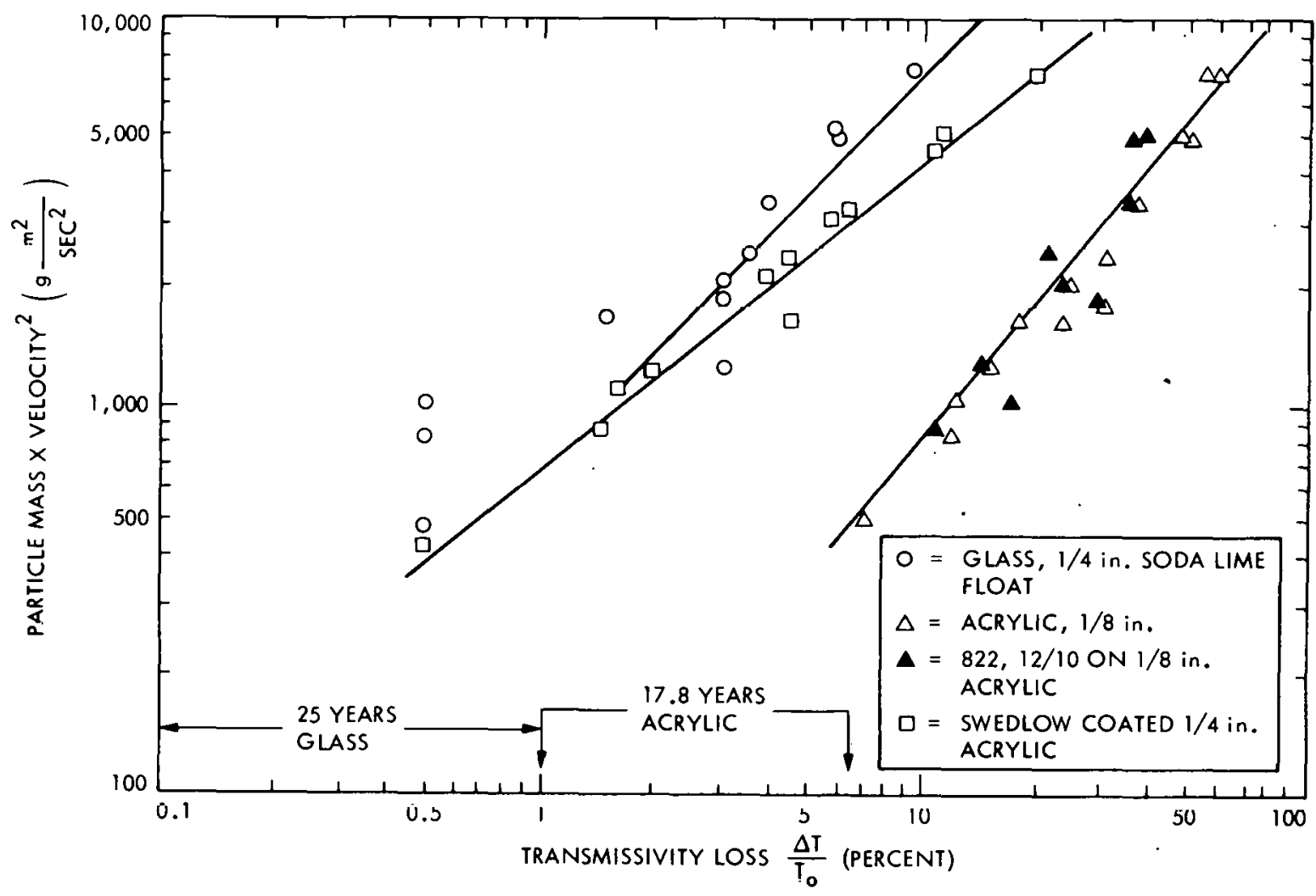

Figure 23. Velocity Parameter Versus Transmissivity Loss for Soda Lime Glass and Plastic (Ref. 77) 


\section{SECTION V}

CONCLUSIONS

Considerable research has been performed by JPL and various industrial organizations over the past few years directed toward long-lived, low cost encapsulants suitable for photovoltaic applications. The lack of an organized body of information on the critical properties of glass encapsulants formed the impetus for this report.

The conclusions of this report concerning glass are summarized as follows:

1. The properties of glass are given frequently in terms of average values; therefore, they should be used with caution.

2. Glass properties (particularly expansion) can be tailored to meet a specific application.

3. Processing factors, particularly production volumes, affect the price of glass.

4. Improvements in characteristics of photovoltaic glass can be made in the areas of iron content reduction, tempering and antireflection coatings.

5. Glass is relatively resistant to environmental aging. Tests indicate the borosilicates are less affected than the soda-lime-silicates.

The conclusions concerning the process for selection of candidate glass materials are the following:

1. Soda-lime-silica glasses are, and probably will continue to be, more economical encapsulants than borosilicates on a unit-weight basis.

2. Borosilicate glasses may be necessary for special encapsulation systems in which the glass is integrally bonded to the silicon cells, unless either the glass and/or the cell is extremely thin. 


\section{REFERENCES}

1. Properties of Glasses and Glass-Ceramics, Corning Glass Works, N.Y., August, 1973.

2. British Glass Industry, Directory and Buyers' Guide, 7th Ed., Illiff \& Sons, Ltd., 1959.

3. Holloway, D. G., The Physical Properties of Glass, Springer-Verlay, N.Y., 1973.

4. Duncan, G. S., Bibliography of Glass, Pall Mall, Sheffield, England, 1960.

5. Shand, E. B., Glass Engineering Handbook, Second Edition, McGraw-Hill Book Co., Inc., N.Y., 1958.

6. Clauser, H. R., The Encyclopedia of Engineering Materials and Processes, Reinhold Publishing Corp., Chapman \& Hall, N.Y., 1963.

7. The Händbook of Glass Manufacture, Volume II, Fay V. Tooley, Editor; Books for Industry, Inc., and Glass Industry Magazine, Divisions of Magazines for Industry, Inc., 1974, p. 744.

8. Gray, D., Editor, American Institute of Physics Handbook, McGraw-Hill Co., Inc., N.Y., 1963.

9. Weast, R. C., and Astle, M. H., CRC Handbook of Chemistry and Physics, 59th Ed., CRC Press, Inc., West Palm Beach, FL, 1978.

10. Bolz, R. E. and Tuve, G. L., Handbook of Tables for Applied Engineering Science, Chemical Rubber Co, Cleveland, Ohio, 1970.

11. Lillie, H. R., Glass, Chapter 7, Handbook of Physics, McGraw-Hill Book Co., Inc., N.Y., 1958.

12. Weyl, W. A., Coloured Glasses, Society of Glass Technology, Sheffield, S105B5 England, 1976.

13. The Glass Industry Directory Issue 59 (10), 1977-1978.

14. Glass Factory Directory Issue of American Glass Review, January 31, 1959.

15. European Glass Directory and Buyers Guide, Fuel and Metallurgical Journals Ltd., 21 John Adams Street, London, England WCZN. 6JH 1977.

16. Tooley, Fay V., The Handbook of Glass Manufacture, Vol. II. Books for Industry, Inc., New York, New York, 1974, p. 712. 
17. Hammond, A. L., Energy and the Future, AAAS, Washington, D.C., 1973, p. 61.

18. Noll, E. M., Wind, Solar Energy, Howard W. Sams \& Co., Inc., 1975.

19. Meinel, A. B. and Meinel, M. P., Applied Solar Energy, Addison-Wesley Publishing Co., Reading, MA, 1977.

20. Duffie, J. A., and Beckman, W. A., Solar Energy Thermal Processes, Wiley, 1974.

21. Considine, D. M., Energy Technology Handbook, McGraw-Hill Book Co., Inc., 1977.

22. Flinn, R. A., and Trojan, F. K., Engincering Matcrials and Their Applications, Houghton Mifflin Co., Boston, 1975.

23. Bouquet, F., Glass for Solar Concentrator Application, JPL Report 5102-105, Apri1 1, 1979.

24. Jordan, J. F., Development of Low Cost Solar Cells, Workshop Proceedings, Photovoltaic Conversion of Solar Energy for Terrestrial Applications, Cherry Hill, New Jersey, October 23-25, 1973, NSF-RA-N-74-013, pp. 182-192.

25. Lind, M. A. and Rusin, J. M., Heliostat Glass Survey and Analysis, BattelleiNL, PNL-2868 UC-62, September 1978.

26. Taketani, H., et al, Mirrors for Solar Energy Application, McDonnell Douglas Astro, Co., West MDC G 7213, September 1977.

27. Rauch, H. W., Sr., ULrich, D. K., and Green, J. M., Glasses Designed for Use as Integral Solar Cell Covers, Conference Kecord of 'lenth LEEE Photovoltaic Specialists Conference, November 13-15, 1973, Palo Alto, California, 1974.

28. Carmichae1, C. C. et al, Review of World Experience and Properties for Encapsulation of Terrestrial Photovoltaic Arrays, Battelle-Columbus Laboratories, ERDA/JPL̈ 954328-7614, July 21, 1976.

29. Treble, F. C., Process in Advanced Solar Array Development, Presented at the Eighth IEEE Photovoltaic Specialists Conference, August, 1970, Seattle, Washington.

30. Innotech Glass Products, Innotech Corporation, Norwalk, Connecticut, November 4, 1975.

31. Perri, J. A., Glass Encapsulation, in Microelectronic Technology, Samuel L. Marsha-1 Ed., Boston Technical Publishers, Inc., 1967, pp. 215-217. 
32. Phillips, C. J., Glass, Its Industrial Applications, Reinhold Publ. Co., N.Y., 1960.

33. Module/Array Interface Study, Final Report 1978, DOE/JPL - No. 954698-78/ 1A, Bechtel National, Inc., August 1978.

34. Coulbert, C. D., Development \& Validation of a Life-Prediction Methodology for LSA Encapsulated Modules, DOE/JPL 5101-40, June 8, 1977.

35. Material Cost Index, Ceramic Industry, January, 1976, p. 17.

36. Watt, G. R., Boron, Mining Engr. 28, No. 3, 1976, pp. 30-31.

37. Wiser, G. L., New Materials in Aircraft Windshields, SAE Paper 700862, Presented at National Aeronautic and Space Engineering and Manufacturing Meeting, October 519, Los Angeles, California, -970.

38. Olson, J. B., Deslgn Considerations Affecting Performance of Glass/Plastic Windshields in Airline Service, Aircraft Engineering, 47, November, 1975, pp. $4-12,26$.

39. Poole, J. P., and Snyder, H. C., Chemically Strengthened Glass Containers by Ion Exchange, Glass Tech., 16 (5), 1975, 109-113.

40. Ball, G. L., III, Wilken, P. H., North, C. J., and Salyer, I. O., A Thermoplastic Transparent Adhesive for Bonding Polycarbonate to Glass, Monsanto Research Corp. Report No. MRC-DA-296, July, 1971.

41. Wiser, G. L., Glass/Plastic Composile W1ndshields, SAMPE Journal, 6, $1952,29-35$.

42. Ward, J., Towards Invisible Glass, Vacuum, 22 (9), September, 1972, $369-375$.

43. Seibert, G., Incrased Solar Cell Output by Improved Optical Matching Part I - Theoretical Considerations, European Space Résearch \& Technology (Netherlands), ESRO-TN-90-/ESTEC, March, 1969.

44. Wang, E. Y., Yu, F. T. S., Simms, V. L., and Brandhorst, H. W., Jr., Optimum Design of Antireflection Coating for Silicon Solar Cells, Conference Record of the Tenth IEEE Photovoltaic Specialists Conference, November 13-15, 1973, Palo Alto, California, 1974.

45. Wang, E. Y., Covering Factor of Optically Coated Silicon Solar Cells, Opt. Eng., 14 (2), March-Apri], 1975, 176, 177.

46. Seibert, G., Increased Solar Cell Output by Improved Optical Matching Part 2 - Experimental Results, European Space Research \& Technology CenLer (Netherlands), Pret. No. ESRO-TN-91, April, 1969. 
47. Crabb, R. L., Evaluation of Cerium Stabilized Microsheet Covers for Higher Solar Cell Outputs, Presented at the Ninth IEEE Photovoltaic Specialists Conference, May 2-4, 1974, Silver Spring, Maryland.

48. Luft, W., Status of $\mathrm{TiO}_{\mathrm{x}}$ Antireflective Coating in U.S., Conference Record of the Tenth IEEE Photovoltaic Specialists Conference, November 13-15, 1973, Palo Alto, California.

49. Lindmayer, J., et a1., Development of $20 \%$ Efficient Solar Cell, Progress Report, June to September 1974, Solarex Corp., NSF/Rann/SE/GI-43090/PR/ $74 / 3$.

50. Nico1l, F. H., A New Chemical Method of Reducing the Reflectance of Glass, KL:A Kev1ew, 1942, 6, 287, 301.

51. Thomsen, S. M., Low-Reflection Films Produced on Glass in a Liquid Fluusilicic Acid Bath, RCA Review, Marcy, 1951, pp. 143-149.

52. Mar, H. Y. B., et al., Optical Coatings for Flat Plate Solar Collectors, Final Report Contract No. NSF-C-957 (AER-74-09104), Honeywel1, Inc., September, 1.974-1975.

53. Peterson, R. E., and Ramsey, J. W., Thin Film Coatings in Solar-Thermal Power Systems, J. Vac. Sci. Technol., 12 (1), 1975, 174-181.

54. Mattox, D. M., Solar Energy Materials Preparation Techniques, J. Vac. Sci. Technol., 12 (5) 1975, 102:3, 1031.

55. Beauchamp, E. K., Low Reflectance Films for Solar Cullector Cover Plates, SAND75-0035 March, 1975.

38. Hullalian, J. R., Wydeven, T., and Johnson, C. C., Combination for Moisture Resistant and AnLireflection Plasma Polymerized Thin Films for Upticál Coatings, Applied Optics, 13 (8) 1974, 1044-1849.

57. Hollahan, J. R., and Wydeven, 'l'., Protection of Moisture Sensitive Optical Components With Polymer Coatings, U.S. Patent Application 402,866 February $10,1973$.

58. Tien,.P. K., Smolinsky, G., and Martin, R. J., Thin Organosilicon Films for Integrated Upe1es, App1. Opt. 11 (3) March, 1977, 6.37-42.

59. Shirokshina, Z. V., Antireflection and Protective Coatings of Components Made From Lead Germanate Glasses, Sov. J. Opt. Technol, (USA), 41 (9), September, 1974, 411-12.

60. Koch, J., Keduction of Reflectivity From Transparent Materials: A Memorandum in Evaluation of Techniques Applicable to Plastic Helicopter Canopies, Nature, 164 (4157), July, 1949. 
61. Beach, N. E., Reduction of Reflectivity From Transparent Materials: A Memorandum in Evaluation of Techniques Applicable to Plastic Helicopter Canopies, Plastics Technical Evaluation Center, Dover, New Jersey, Report No. PLASTEC-9 July, 1962.

62. Shank, C. V., and Schmidt, R. V., Optical Technique for Producing o.1-u Periodic Surface Structures, App1., Phys, Lett. (USA), 23 (3), August 1, $1973,154-5$.

63. Snogren, R., Handbook of Surface Preparation Palmerton Publ. Co., N.Y. (1974), p. 404-5.

64. Trivisonno, M. N., et al, Adhesion of Polyester Resin to Treated Glass Surfaces, Industrial and Engineering Chemistry, June 1958.

65. Sterman, S, and Toogood, J. B., How to Promote Adhesion with Silicones and Silanes, Adhesives Age, July 1965.

66. Plueddemann, E. P., Chemical Bonding Technology for Terrestrial Solar Cell Modules, JPL Report 5101-132 dated September 1, 1979.

67. Sheratte, M. B., Cleaning Agents and Techniques for Concentrating Solar Collectors, MDC G8131, September 1979.

68. Communication with Mr. Al R. Hoffman, JPL.

69. Gonzalez, C., Environmental Hail Model for Assessing Risk to Solar Col.1ectors, JPL 5101-45, Decomber 6, 1977.

70. Moore, D. M., Proposed Method for Determining the Thickness of Rectangular Glass Solar Collector Panels Subjected to Uniform Normal Pressure Loads DOE/JPL (to be published).

71. Harrison, T. D., Midtemperature Solar Systems Test Facility Results; Effects of Severe Hailstorm on August 9, 1978., SAND 78-2182, March 1979.

72. Twelfth Project Integration Meeting Handout, JPL, Apri1. 4 and 5, 1979, 5101-110.

73. Technical Service Report No. 101A, Wind Load Performance, PPG Industries, Undated.

74. Sonneborn, R. H., Fiberglas Reinforced Plastics, Reinhold Publ. Co., N.Y., 1954.

75. Tcai, C. R., and Stewart, R. A., Stress Analysis of Large Detlection of Glass Plates by the Finite-Element Method, J. Am. Ceramic Society, Vol. 59, No. 9-10, May $11,1976$.

76. PPG Glass Thickness Recommendations to Meet Architects' Specified 1-Minute Wind Load, Technical Services/Flat Glass Division, April 23, 1979. 
77. Taketani, H., and Arden, W. M., Specular Mirrors for Solar Energy Applications, SAMPE Quarterly, October 1978, pp. 54-63.

78. Walters, H. V. and Adams, P. B., Effects of Humidity on the Weathering of Glass, Journal of Non-Crystalline Solids, 19, 1975, pp. 183-99. 
GLOSSARY

The folluwing definitions have been selected mainly from ASTM Desig. c162-49T, compiled jointly by the American society of Testing Materials and the American Ceramic Society. Other definitions are marked with an asterisk(*). Those followed by the letters RFP apply to fibrous-glass reinforced plastics and are adopted from Sonneborn.

AM0, AM1, and AM2. These notations refer to the amount of air mass between the sun and the solar cell. AM0 would be the response of the solar cell in space, AMl on earth with the sun vertically overhead and AM2 with the light passing through two air masses.

Anneal. To prevent or remove objectionable stresses in glassware by controlled cooling from a suitable temperature.

Annealing Point. The temperature at which the glass is brought to a temperature high enough to relieve internal stresses throughout, but not so high as to mark or deform it. The upper tempcrature limil is close to its "annealing point".

Batch. The raw materials, properly proportioned and mixed, for delivery to the furnace.

Bevel. The difference in length between the upper and lower surface of the glass at the cdge after cutting.

*Binder (F1brous Glass). Substances employed to bond or hold the fibers together.

Blank. See lite.

Blister. An imperfection; a relatively large bubble or gaseous inclusion.

Rlnwipe. The pipc used by a glassmaker for gathering and blowing by mouth.

Bubbles. Gas inclusions in any glass.

Check. A surface crack or imperfection in glass surface.

Deformation Point. The temperature observed during the measurement of expansi$v$ ity by the interferomeler method at which vicous flow exactly counteracts thermal expansion. The deformation point generally corresponds to a viscosity in the range from $10^{11}$ to $10^{12}$ poises.

Devitrification. Crystallization in glass.

Dice. The more or less cubical fracture of tempered glass.

Digs. Deep short scratches. 
Feeder. A mechanical device for regularly producing and delivering gobs of glass to a forming unit.

Fiber. An individual filament made by attenuating molten glass. A continuous filament is a glass fiber of great or indefinite length. A staple fiber is a glass fiber of relatively short length (generally less than 17 in.).

Fining. The process by which the molten glass approaches freedom from undissolved gases.

Fine Annealing. Annealing to an extremely low stress and uniform index of refraction.

Flare. An extension of glass remaining or absent from the surface of the glass shept raused by llie Lutting prococe.

Flint glass. (1) A lead-containing glass. (2) Term used by container industry for colorless glass.

Flux. A substance that promotes tusion.

Forehearth. A sectiun of a furnacc, in one of several forms, from which glass is taken for forming.

Gaffer. Head workman, foreman, or blower of a glass hand shop.

Gaseous Inclusions. Round or elongated bubbles in the glass.

Gather (n.). The mass of glass picked up by the hand shopworker on the punty or blowing iron.

Gather (v.). To get glass tröm a pul u Lank on the pipo or punty.

Glass Ceramic. A material meltcd and formed as a glass, then converted largely to a crystalline form by processes of controlled devitrification.

Heat Treated. Term sometimes used for tempered glass. See Tempered glass.

*Lay-up (FRP). The resin-impregnated reinforcing material. Also the process of making a lay-up.

Lehr or Lear. A long, tumlel-shaped oven for annealing glass by continuous passage.

Liquidous Temperature. The maximum temperature at which equilibrium exists between the molten glass and its primary crystalline phase.

Lite. A section of glass sold and/or handled separately such as a $2 \mathrm{ft} \times 2 \mathrm{ft}$ section. Also called "blank" or "light".

Marver. (1) A flat plate on which a hand gather of glass is rolled, shaped, and cooled. (2) Also the processing of doing same. 
* Mat (Fibrous Glass). A layer of intertwined fibers bonded with some resinous material or other adhesive.

Mold. A form (usually meta1) in which glass is shaped.

Nu-value. Expressed by the Greek letter $\nu$ or by the English letter V. Designates reciprocal dispersive power of glass and is computed as follows:

$$
\text { Nu-value }=\frac{n_{D}-1}{\eta_{F}-\eta_{C}}
$$

where $\eta_{D}, n_{F}$, and $\eta_{C}$ are the refractive indecies at sodium $D(5893 \mathrm{~A})$, hydrogen $\mathrm{F}(4861 \mathrm{~A})$ and hydrogen $\mathrm{C}$ lines (6563A) respectively.

Opal Glass. Glass with fiery translucence. Loosely, any translucent glass.

*Preform (FRP). The process whereby cut strands of roving are drawn by suction onto a shaped screen, sprayed with binder, and cured in an oven. Also, the article made by this process.

*Preloaded (FRP). Containing or combined with the full complement of resin before molding.

Punty. (1) A gathering iron or solid cross section. (2) A device to which ware is attached for holding during fire polishing or finishing.

Ream. Inclusions within the glass, producing a wavy appearance.

Residual Stress. The average tensile stress remaining in the glass after manufacture.

Seam (v.). To slightly grind the sharp edges of a piece of glass.

Seed. An extremely small gaseous inclusion in glass.

Shear Mark. A scar appearing in glassware, caused by the cooling action of the cutting shear.

Size (Textile). Any coating applied to textile fibers in the operation of forming.

Softening Point. The temperature at which a uniform fiber, 0.5 to $1.0 \mathrm{~mm}$ in diameter and $22.9 \mathrm{~cm}$ in length, elongates under its own weight at a rate of $1 \mathrm{~mm}$ per min when the upper $10 \mathrm{~cm}$ of its length is heated in a prescribed furnace at the rate of approximately $5^{\circ} \mathrm{C}$ per min. For a glass of density near 2.5, this temperature corresponds to a viscosity of $10^{7.6}$ poises.

Solarization. Change in transmission of glass as a result of exposure to sunlight or other radiation. 
Squareness. The difference between the two corner-to-corner diagonals of a square or rectangular shape.

Stone. An imperfection/ crystalline contaminations in glass.

Stones. Any opaque or partially melted particle of rock, clay or batch ingredient embedded in the glass.

Strain Point. This is the temperature at which the internal stresses are reduced to low values in 4 hours. At this viscosity, the glass is substantially rigid.

Striking. Development of color or opacity during cooling or reheating.

Tempered Glass. Glass that has been rapidly cooled from near the softening point, under rigorous control, to increase its mechanical and thermal endurance. It also may be tempered chemically.

*Textile Fibers (Fibrous Glass). Fibers or tilaments that can be processed into a yarn or made into a fabric by interlacing in a variety of methods, including weaving, knitting, and braiding.

Thermal Endurance. The relative ability of glassware to withstand thermal shock.

Total Solar Transmittance. The calculated transmittance of solar energy using the solar data for air mass 1.5 and incident upon a perpendicular surface.

*Twisting (Textile). An operation by which a strand or sliver is given a preestablished number of turns per inch and is thus converted into yarn, thread, or cord.

Vee-Chip. Decp "V" shaped chip at glass edge.

*Warp (Textile). Yarns extending lengthwise in the loom and crossed by the filling yarns.

Wave. Defects resulting from irregularities in the surfaces of glass, making the viewed objects appear wavy or bent.

Weathering. Attack of a glass surface by atmospheric elements.

Wired Glass. Flat glass with embedded wire.

Wool. Fleecy mass of plain glass fibers.

Working Range. The range of surface temperature in which glass is formed into ware in a specific process. The "upper elld" tefers lo the lempelalule di which the glass is ready for working (generally corresponding to a viscosity of $10^{3}$ to $10^{4}$ poises), while the "lower end" refers to the temperature at which it is sufficiently viscous to hold its formed shape (generally corresponding to a viscosity greater than 10 poises). For comparative purposes, when no specific process is considered, the working range of glass is assumed to correspond to a viscosity range from $10^{4}$ to $10^{7.6}$ poises. 